In cooperation with

NEW YORK STATE DEPARTMENT OF ENVIRONMENTAL CONSERVATION

\title{
Ground-Water Quality in the Chemung River Basin, New York, 2003
}



U.S. Department of the Interior

U.S. Geological Survey 
This page has been left blank intentionally. 


\section{Ground-Water Quality in the Chemung River Basin, New York, 2003}

By Kari Hetcher-Aguila

Open-File Report 2004-1329 


\title{
U.S. Department of the Interior \\ Gale A. Norton, Secretary
}

\section{U.S. Geological Survey Charles G. Groat, Director}

\author{
U.S. Geological Survey, Reston, Virginia: 2005 \\ For additional information about this report write to: \\ U.S. Geological Survey \\ 30 Brown Road \\ Ithaca, NY 14850 \\ Email: askny@usgs.gov \\ World Wide Web: http://ny.usgs.gov/ \\ For more information about the USGS and its products: \\ Telephone: 1-888-ASK-USGS \\ World Wide Web: http://www.usgs.gov/
}

Any use of trade, product, or firm names in this publication is for descriptive purposes only and does not imply endorsement by the U.S. Government.

Although this report is in the public domain, permission must be secured from the individual copyright owners to reproduce any copyrighted materials contained within this report. 


\section{Contents}

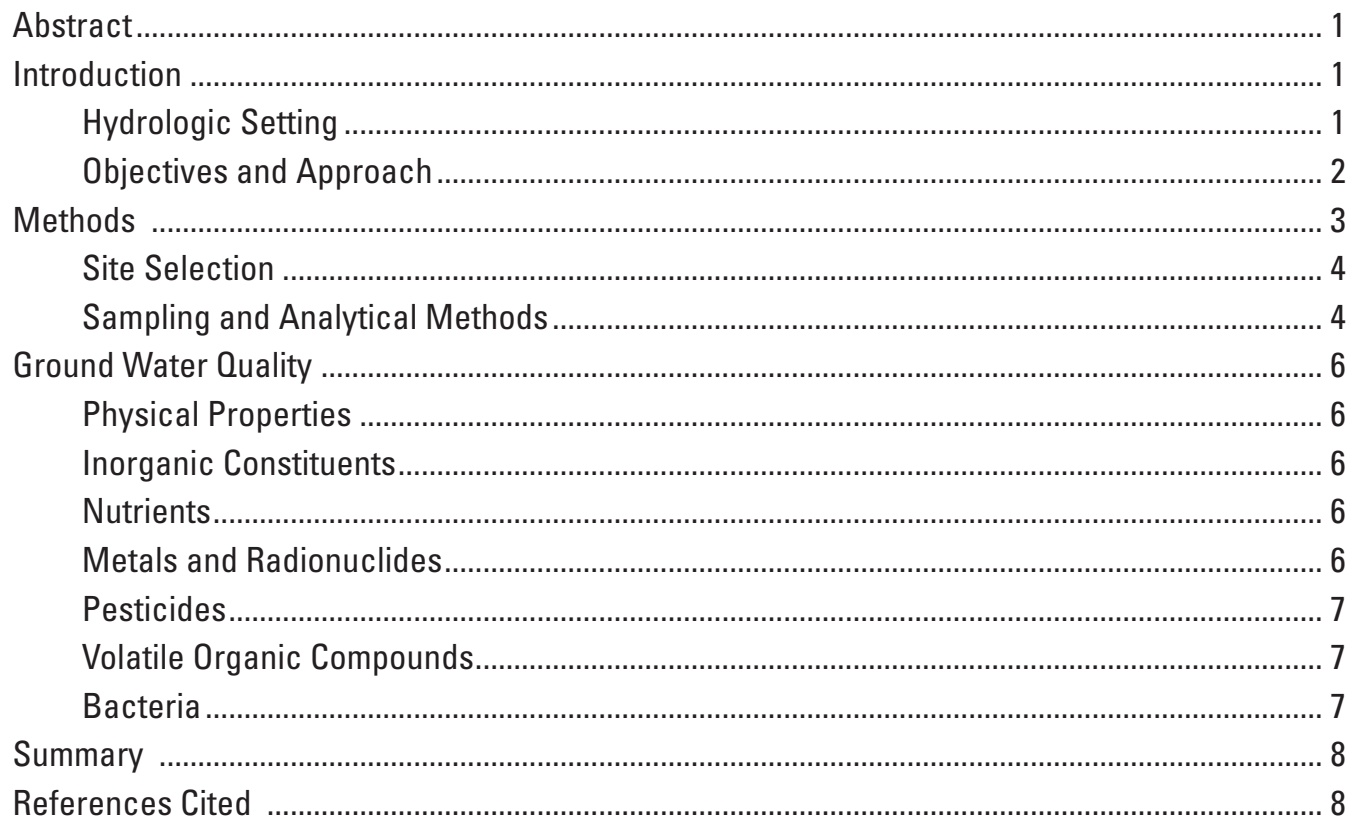

\section{Figures}

1. Principal geographic features of Chemung River basin, New York .............................................. 2

2. Surficial geology of Chemung River basin and locations of wells sampled in 2003 study ........... 3

\section{Tables}

1. Well information and physical properties of ground-water samples from selected wells in the Chemung River basin, New York, 2003

2. Constituents for which ground-water samples from the Chemung River basin, New York, were analyzed but not detected, 2003

3. Concentrations of inorganic constituents in ground-water samples from the Chemung River basin, New York, 2003.

4. Concentrations of nutrients in ground-water samples throughout the Chemung River basin, New York, 2003

5. Concentrations of metals and radionuclides in ground-water samples from the Chemung River basin, New York, 2003

6. Concentrations of pesticides detected in ground-water samples from the Chemung River basin, New York, 2003

7. Concentrations of Volatile Organic Compounds (VOCs) in ground-water samples from the Chemung River basin, New York, 2003

8. Concentrations of bacteria in ground-water samples from the Chemung River basin, New York, 2003 


\section{Conversion Factors and Abbreviations}

\begin{tabular}{lcl}
\hline Multiply & By & To obtain \\
\hline & Length & \\
inch (in.) & 2.54 & centimeter $(\mathrm{cm})$ \\
foot (ft) & 0.3048 & meter $(\mathrm{m})$ \\
mile (mi) & 1.609 & kilometer $(\mathrm{km})$ \\
\hline
\end{tabular}

Temperature in degrees Celsius $\left({ }^{\circ} \mathrm{C}\right)$ may be converted to degrees Fahrenheit $\left({ }^{\circ} \mathrm{F}\right)$ as follows:

$$
{ }^{\circ} \mathrm{F}=\left(1.8 \times^{\circ} \mathrm{C}\right)+32
$$

Other abbreviations used in this report

micrograms per liter $(\mu \mathrm{g} / \mathrm{L})$

milligrams per liter $(\mathrm{mg} / \mathrm{L})$

picocuries per liter $(\mathrm{pCi} / \mathrm{L})$

tritium units (TU)

microsiemens per centimeter $(\mu \mathrm{S} / \mathrm{cm})$ 


\title{
Ground-Water Quality in the Chemung River Basin, New York, 2003
}

\author{
By Kari Hetcher-Aguila
}

\section{Abstract}

Water samples were collected from 24 public-supply wells and 13 private residential wells during the summer of 2003 and analyzed to describe the chemical quality of ground water throughout the Chemung River basin, upgradient from Waverly, N.Y, on the Pennsylvania border. Wells were selected to represent areas of heaviest ground-water use and greatest vulnerability to contamination, and to obtain a geographical distribution across the 1,130 square-mile basin. Samples were analyzed for physical properties, inorganic constituents, nutrients, metals and radionuclides, pesticides, volatile organic compounds, and bacteria.

The cations that were detected in the highest concentrations were calcium and sodium; the anions that were detected in the greatest concentrations were bicarbonate, chloride, and sulfate. The predominant nutrient was nitrate. Nitrate concentrations in samples from wells finished in sand and gravel were greater than in those from wells finished in bedrock, except for one bedrock well, which had the highest nitrate concentration of any sample in this study. The most commonly detected metals were aluminum, barium, iron, manganese, and strontium. The range of tritium concentrations (0.6 to 12.5 tritium units) indicates that the water ages ranged from less than 10 years old to more than 50 years old. All but one of the 15 pesticides detected were herbicides; those detected most frequently were atrazine, deethylatrazine, and two degradation products of metolachlor (metachlor ESA and metachlor OA), which were the pesticides detected at the highest concentrations. Not every sample collected was analyzed for pesticides, and pesticides were detected only in wells finished in sand and gravel. Volatile organic compounds were detected in 15 samples, and the concentrations were at or near the analytical detection limits. Total coliform were detected in 12 samples; fecal coliform were detected in 7 samples; and Escherichia coli was detected in 6 samples. These bacteria were detected in water from bedrock as well as sand-and-gravel aquifers.

Federal and State water-quality standards were exceeded in several samples. Two samples exceeded the chloride U.S. Environmental Protection Agency Secondary Maximum Contaminant Level of 250 milligrams per liter. The U.S. Environmental Protection Agency Drinking Water Advisory for sodium (30 to 60 milligrams per liter) was exceeded in
11 samples. The upper limit of the Secondary Maximum Contaminant Level range for aluminum (200 micrograms per liter) was exceeded in one sample. The Maximum Contaminant Level for barium (2,000 micrograms per liter) was exceeded in one sample. The Secondary Maximum Contaminant Level for iron (300 micrograms per liter) was exceeded in 11 samples. The Secondary Maximum Contaminant Level for manganese (50 micrograms per liter) was exceeded in 20 samples. The proposed Maximum Contaminant Level for radon (300 picocuries per liter) was exceeded in 34 samples.

\section{Introduction}

Section 305(b) of the Federal Clean Water Act Amendments of 1977 (U.S. Environmental Protection Agency, 1997) requires states to undertake a comprehensive water-quality monitoring program for surface-water and ground-water resources. The New York State Department of Environmental Conservation (NYSDEC) Rotating Intensive Basin Study routinely monitors surface water to fulfill one portion of this requirement, but historically ground water has been less frequently monitored. In 2002, the U.S. Geological Survey (USGS), in cooperation with the NYSDEC, and with input from the U.S. Environmental Protection Agency (USEPA), developed a plan to sample ground water in various aquifers within the Chemung River Basin (fig. 1).

\section{Hydrologic Setting}

The Chemung River basin $\left(1,130 \mathrm{mi}^{2}\right)$ lies mostly in southwestern New York and partly in north-central Pennsylvania (fig. 1). The main valley of the Chemung River trends northwest-southeast, is about 1 mile wide in most places and empties into the Susquehanna River, south of Waverly, N.Y., in Pennsylvania.

The glacial and alluvial sediments within the Chemung River valley are as much as 500 feet thick (Miller, 1982) and form unconfined and confined aquifers that supply water to the villages and cities throughout the basin, including the cities of Elmira, Corning, and Bath (fig. 1). The main valley intersects northeast-southwest trending glaciated tributary valleys 


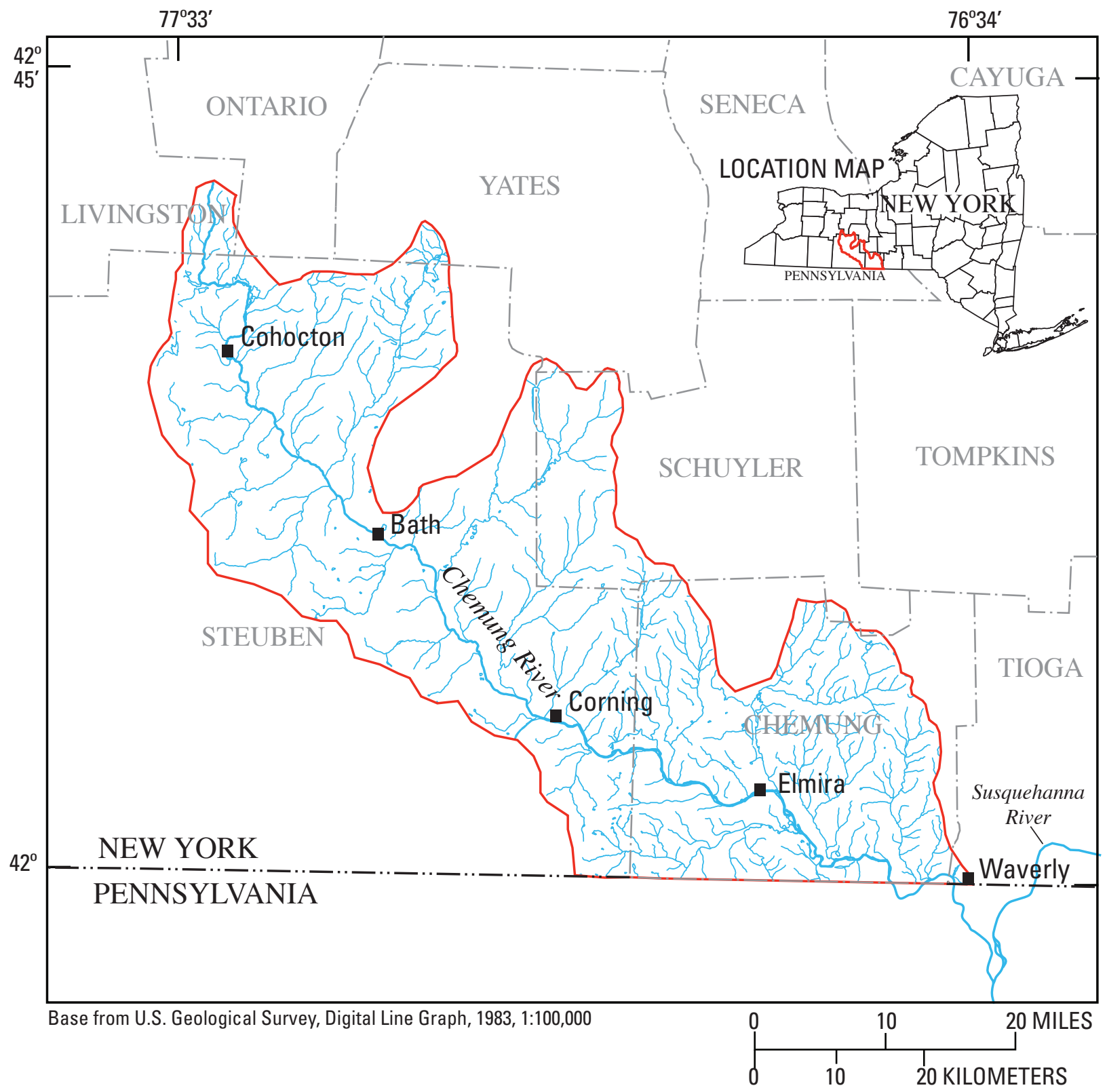

Figure 1. Principal geographic features of Chemung River basin, New York.

that are filled with Pleistocene glacial sediments (outwash, kames, lacustrine deposits, and till) and Recent deposits from the small tributaries that flow within these valleys (fig. 2). Surrounding the tributary valleys are bedrock uplands that generally consist of a thin layer of till on top of nearly flatlying shale, siltstone, and fine-grained sandstone bedrock, and rise as high as 900 feet above the valley floor.

\section{Objectives and Approach}

In 2002, the USGS, in cooperation with the NYSDEC, began a program to evaluate ground-water quality throughout selected river basins in New York to fulfill the requirements of Section 305(b) of the Federal Clean Water Act Amendments of 1977 (U.S. Environmental Protection Agency, 1997). As part of this program, a ground-water-quality study was conducted in the Chemung River basin during the summer of 2003. The study addressed only the part of the basin that lies within New York (fig. 1). Ground-water was sampled throughout the basin from sand and gravel aquifers and bedrock aquifers for water-quality analysis to identify (1) areas with potential ground-water-contamination, (2) waterquality differences between the bedrock and the sand and gravel aquifers, and (3) water-quality differences between the main valley and the forested uplands. Sampling was done at public-supply wells and private residential wells. Analytical results from both types of wells were compared with USEPA and NYSDEC water-quality standards to depict a pattern of ground-water quality throughout the basin. 


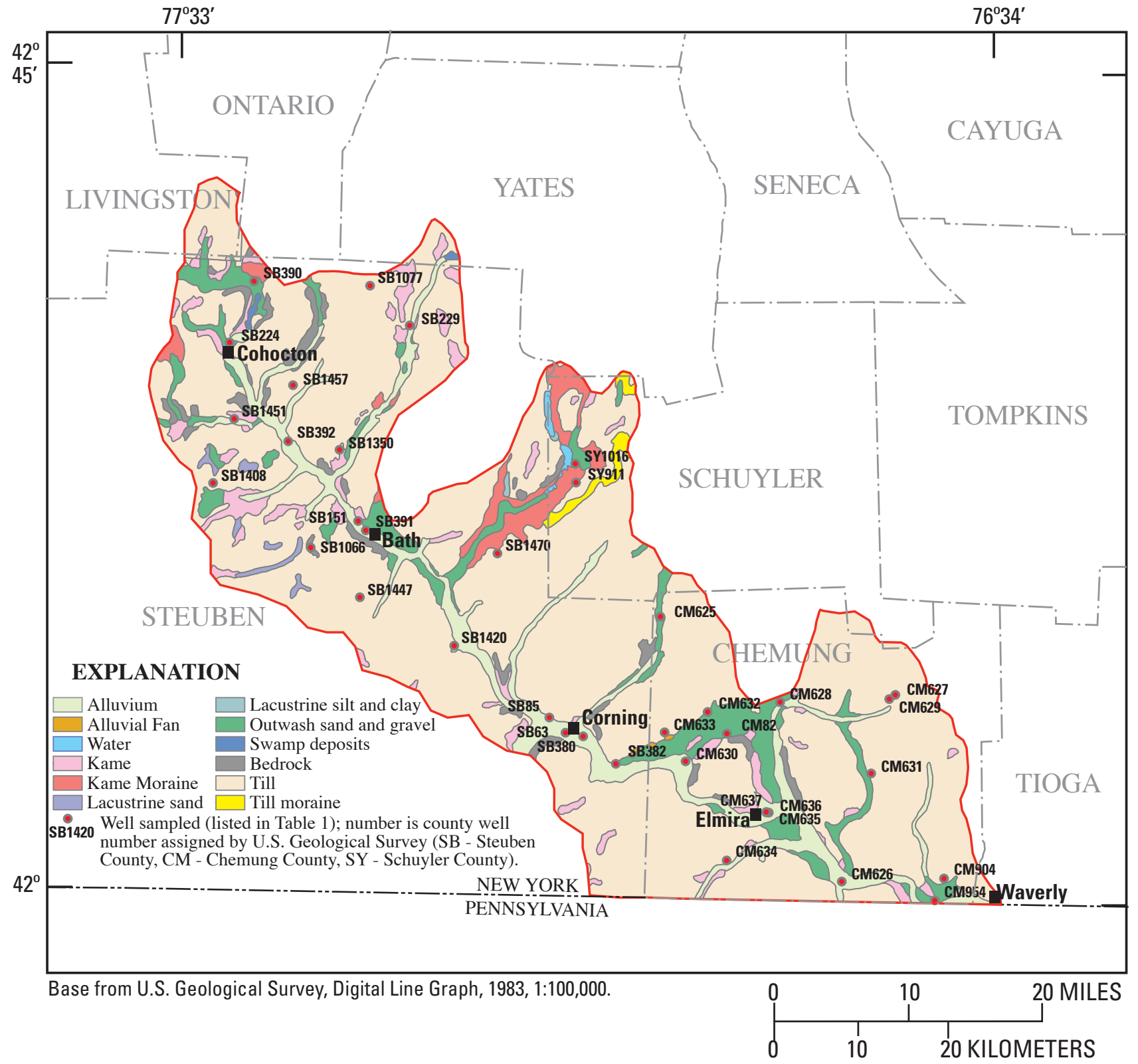

Figure 2. Surficial geology of Chemung River basin and locations of wells sampled in 2003 study (Cadwell, 1991). (Well data are given in table 1.)

This report presents the results of the water-quality analyses conducted on ground-water samples collected in 2003 from 37 wells in the Chemung River basin in New York. The samples were collected from 24 public-supply wells and 13 private residential wells. Samples were analyzed for physical properties, major inorganic constituents, nutrients, metals, radionuclides, pesticides, volatile organic compounds, and bacteria. Results of the analyses are presented in 8 tables at the end of this report. Analytical results for selected constituents are compared to the Maximum Contaminant Levels (MCLs) and Secondary Maximum Contaminant Levels (SMCLs) established by the USEPA.

\section{Methods}

Water samples were collected from 37 wells throughout the Chemung River basin and analyzed for 209 constituents and physical parameters. This section describes the criteria used to select these 13 private residential wells and 24 publicsupply wells, the sampling methods used in the field, and the analytical methods used. Any anomalous sampling procedures that were required are also described. 


\section{Site Selection}

Residential wells were identified in the USGS GroundWater Site Inventory (GWSI) database and through the NYSDEC Water-Well Reporting Program. The Water-Well Reporting Program was implemented in 2000 to collect information about newly drilled wells throughout New York from licensed well drillers, and is useful in locating wells suitable for ground-water studies. Once a well was identified as a potential sampling site, a letter was sent to the owner of the well. The letter described the project, requested permission to sample the water, and included a questionnaire asking the location of the well, the most convenient times for sampling, any safety concerns around the well, and other well-related information. Well owners who did not return the questionnaire received a phone call to ask permission to sample the well water and for other information about the well. Well owners who did return the questionnaire or who gave permission to sample their well during a phone call were contacted approximately one week before sampling to set up a date and time to sample their well.

Public-supply wells were identified in the GWSI database, and through contact with local officials (including the Cornell Cooperative Extension in Elmira, the Chemung and Steuben County Departments of Health, and the Chemung County Soil and Water Conservation District), and the water managers of villages and cities throughout the basin. The water managers were then sent letters containing a project description and questionnaire similar to that sent to residentialwell owners. Phone calls were made to clarify any questions about the wells and to set up a date and time to sample the wells.

Site selection did not target specific municipalities, industries, or agricultural practices; rather, sample sites were selected to represent areas of greatest ground-water use and greatest vulnerability to contamination, and to obtain a thorough geographical distribution of the entire basin (fig. 2). Site selection included (1) wells finished in sand and gravel and wells finished in bedrock; (2) wells in the main valley of the Chemung River, in the tributary valleys, and in the uplands surrounding the valley; (3) wells in each of four land-use categories-predominantly agricultural, forested, urban, or mixed; and (4) public-supply and residential wells.

The land-use categories were used only to describe the wells and the area surrounding them within a half-mile radius, and can overlap. For example, a residential well finished in sand and gravel might be in either the main valley or in the uplands and may be surrounded by forest or agricultural land. Most wells finished in sand and gravel were in the valleys, however, and ranged from 30 to 110 feet deep, whereas most bedrock wells were in the uplands and ranged from 94 to 330 feet deep. Well data, land-use data, and water-quality data are given in table 1.

Shallow sand and gravel wells within the valleys are susceptible to contamination of various types including volatile organic compounds (VOCs), pesticides, deicing chemicals, and nutrients from nearby industries, highways, agriculture, and residential areas, and the movement of these contaminants to the water table is generally relatively rapid. The bedrock wells in the uplands are less susceptible to contamination from industrial and urban sources because the industries, roads, and residential areas are mainly in the valleys below, and because water generally takes longer to move from land surface into the bedrock through the surficial materials. The rural areas surrounding most upland wells are a potential source of contamination from agricultural chemicals, animal wastes, and septic systems, however, and these sources can make the upland wells more susceptible than valleybottom wells to nutrients and pesticide contamination.

Well designation according to predominant land use within a half-mile radius of the well provides a general indication of the type of contamination that can be expected; for example, water from wells surrounded by predominantly agricultural land could have elevated concentrations of nutrients or pesticides, whereas water from wells surrounded by mixed land uses (industrial, commercial, parks, highways) might have elevated concentrations of VOCs or pesticides. Water from wells surrounded by predominantly forested, undeveloped land, in contrast, tends to be relatively uncontaminated.

The above method of assigning a land-use category to a well, although relatively easy, does not always accurately denote the land use that affects the water in the well. For example, a well completed in sand and gravel in the main valley of the Chemung River pumps water that could be affected by chemicals discharged several miles upstream. Also, a sample from a well finished in the valley aquifer might contain a mixture of relatively recent water and older water from deep within the aquifer that might have entered the system tens to hundreds of years ago. In addition, a chemical spill within a half-mile of a well might not be reflected in the water sample because it might not reach the well for many years or it could bypass the well entirely. Therefore, using land-use categories as well descriptors provides only a general indication of the potential for contamination, and it is not possible to conclude that specific land uses are affecting specific wells on the basis of a single water-quality analysis. Delineation of the actual flow paths and traveltimes of water at the wells sampled would require extensive sampling, which was beyond the scope of this study.

\section{Sampling and Analytical Methods}

Water samples analyzed for inorganic constituents (table 3), nutrients (table 4), metals and radionuclides (table 5) and VOCs (table 7) were collected from each well and processed by methods described in the USGS national field manual for the collection of water-quality data (U.S. Geological Survey, variously dated). In addition, pesticide samples (table 6) were collected and processed by the methods of Shelton (1994) and Sandstrom and others (2001) and 
analyzed at the USGS National Water Quality Laboratory (NWQL) and the USGS Kansas Organic Geochemistry Research Laboratory (OGRL) for 116 pesticides and pesticide degradates through methods described by Zaugg and others (1995), Meyer and others (1993), and Ferrer and others (1997). The analytical method devised by Zaugg and others (1995), developed in cooperation with the USEPA, detects some of the most commonly used pesticides in the nation. Bacteria samples (table 8) were collected and processed in accordance with NYSDEC and New York State Department of Health (NYSDOH) regulations.

Quality-assurance samples were collected to assess the accuracy and reproducibility of the data. Blank and replicate samples were collected for at least 10 percent of the samples. Blank samples contained either inorganic-grade blank water or pesticide-grade blank water provided by the USGS WaterQuality Services Unit in Ocala, Fla.; the blank samples did not contain any constituents in concentrations above the detection limits of the analytical methods used. Concentrations in the replicate samples had no statistically significant differences.

Sampling entailed the following steps: the well pump was turned on (many of the public-supply wells were already running) and allowed to run as long as 20 minutes, or until at least five casing-volumes of well water had passed the sampling point. A spigot was opened, and the water was allowed to run for several more minutes to flush the spigot. During this time, a general visual evaluation of the area surrounding the sampling site was conducted to identify obvious potential nonpoint sources and point sources of contamination that could affect the water from the well. The latitude and longitude of each well was documented with a global positioning system. Whenever possible, samples were collected from a spigot between the well and any pressure tanks or water treatment systems to ensure that the water collected was representative of the water in the aquifer.

At each sampling site, a Teflon discharge line was connected to the spigot, and samples were analyzed with a multiprobe meter for physical properties, including temperature, specific conductance, dissolved oxygen concentration, and $\mathrm{pH}$. The water was run slowly enough (100 to 250 milliliters $(\mathrm{mL})$ per minute) for the sensors in the container to react, yet fast enough to cause the pump in the well to run continuously (this sometimes required opening other faucets to waste). Once these properties had stabilized, a second Teflon discharge line was connected to the first with a stainless steel quick-connect fitting, and the second line was directed into a sampling-chamber bag mounted on a plastic box. The bottom of the sampling-chamber bag was pierced above a plastic funnel in the top of the box to allow water to run to waste for several minutes to flush the Teflon line. Bottles were filled within the chamber bag according to standard USGS sampling methods described in the USGS field manual (U.S. Geological Survey, variously dated).

Analyses for most physical parameters, most metals, radionuclides, and VOCs were conducted on unfiltered water samples (tables 1, 5, and 7) to determine the whole-water concentrations of these analytes, which best represent the natural concentrations within the aquifer. Concentrations of major inorganic constituents, most nutrients, pesticides, and 3 metals were determined from filtered samples (tables 3, 4, 5 , and 6). Comparison of unfiltered concentrations to filtered concentrations are used to determine the difference between the total and dissolved concentrations of a constituent (for example, filtered and unfiltered iron concentrations in table 5). In addition, concentrations of some constituents can change if left in an unfiltered sample because of changes in temperature, $\mathrm{pH}$, and degradation of the compounds through biologic processes; therefore, a filtered sample is required to determine the concentrations of these constituents in the natural aquifer (for example, pesticides can degrade into other pesticides when left in an unfiltered sample). Nitric acid was also added to some filtered and unfiltered samples to stop biologic degradation of the sample. When a filtered sample was required, a 0.45 micron capsule filter was attached to the Teflon discharge line inside the sample chamber bag; pesticide samples were filtered using a plate filter assembly.

All Teflon discharge lines were cleaned in the laboratory before each sampling day and in the field in between each sampling site. New chamber bags were used at each sampling site. Samples for radon analysis were obtained through a septum chamber with a disposable syringe in accordance with the procedures outlined in the USGS field manual (U.S. Geological Survey, variously dated). Samples for bacterial analysis were collected in sterile containers provided by a NYSDOH-approved laboratory.

All samples were stored on ice in coolers until the end of the sampling day, when each was sent to one of four laboratories: (1) the USGS National Water Quality Laboratory in Denver, Colo., to be analyzed for inorganic constituents (table 3), nutrients (table 4), metals (table 5), some pesticides (table 6), and VOCs (table 7); and (2) the Kansas Organic Geochemical Research Laboratory in Lawrence, Kans. for other pesticide analyses (table 6); (3) the USGS Isotope Laboratory in Menlo Park, Calif. for tritium analyses (table 5); or (4) a local NYSDOH-approved laboratory in Waverly, N.Y., for bacteriological analysis (table 8).

Most well sites allowed easy access to a spigot that was not preceded by treatment or pressure tanks; but five had unusual situations. (1) Wells CM 635, CM 636, and CM 637 (fig. 2) had no spigot-type sampling attachment that preceded the treatment systems, but rather had a metal tube at the top of the well from which a raw sample could be obtained. The Teflon sampling apparatus and chamber bags could not be used at these wells, but the well pump was allowed to run the appropriate length of time and the water was allowed to flush the metal tube for several minutes before the bottles were rinsed and filled. The disposable syringe was inserted into the tube to obtain the best available sample for radon analysis. (2) Well SB1077 (fig. 2) had a spigot, but the pump was not fitted with a flow regulator, and the water came out of the spigot at too high a rate for the Teflon apparatus to be attached. Therefore, the pump was allowed to run the 
appropriate amount of time, and water was allowed to flush the spigot for several minutes before the bottles were rinsed and filled. The radon-sampling apparatus was attached to the spigot, however, and a sample was easily obtained. (3) At well CM 629, the well spigot was in a cellar below a mobile home in a cramped location. Most of the samples from this well were collected at the spigot, but the samples for pesticide and inorganic constituent analyses were collected from an outside spigot. (4) Wells SB 151 and SB 391 did not provide access to a raw, untreated sample because chlorination was done by injection inside the well casing. Samples were taken nevertheless, although some of the analytical results from this site do not represent a raw sample (for example, the bacteriological counts or chloride concentration in these samples are not representative of untreated water). (5) An additional sample was collected at wells SB1408 and SB1066 because the first sample indicated infiltration of surface runoff into the wells from recent heavy rains, which resulted in high turbidity and high bacteriological concentrations in the water; therefore, these wells were resampled about 2 weeks later to obtain a more representative sample. These 2 extra samples are included in the tables at the end of the report for comparison purposes.

\section{Ground Water Quality}

The 39 ground-water samples (two wells were sampled twice) collected during the summer of 2003 were analyzed for 209 constituents and physical properties; more than half (131) of the constituents were not detected in any samples (table 2); the concentrations of the 78 constituents that were detected are listed in tables 3 through 8 . Concentrations of several constituents were above recommended Maximum Contaminant Levels (MCLs) or Secondary Maximum Contaminant Levels (SMCLs) of the U.S. Environmental Protection Agency (1996), the New York State Department of Environmental Conservation (1998), and the New York State Department of Health (1998).

\section{Physical Properties}

Field $\mathrm{pH}$ of all but one of the samples was within the accepted SMCL range (U.S. Environmental Protection Agency, 1996) of 6.5 to 8.5 (table 1); the exception exceeded this range in the field measurement but was less than 8.5 when tested at the laboratory. Specific conductance of the samples (table 1) ranged from 204 to 1,450 microsiemens per centimeter $(\mu \mathrm{S} / \mathrm{cm})$ in the field and from 211 to $1,420 \mu \mathrm{S} / \mathrm{cm}$ at the laboratory. Water temperature (table 1) ranged from 8.6 to $16.1^{\circ} \mathrm{C}$. The color of seven samples exceeded the SMCL of 15 (table 1).

\section{Inorganic Constituents}

The cations that were detected in the highest concentrations were calcium and sodium; calcium values ranged from 8.6 to 105 milligrams per liter $(\mathrm{mg} / \mathrm{L})$; sodium values ranged from 4.1 to $173 \mathrm{mg} / \mathrm{L}$ (table 3 ), and 11 samples exceeded the USEPA Drinking Water Advisory for sodium. This Advisory recommends sodium concentrations in drinking water do not exceed 30 to $60 \mathrm{mg} / \mathrm{L}$ on the basis of taste. This recommendation is not federally enforceable but is intended as a guideline for States (U.S. Environmental Protection Agency, 2002).

The anions that were detected in the highest concentrations were bicarbonate, chloride, and sulfate; bicarbonate values ranged from 107 to $389 \mathrm{mg} / \mathrm{L}$, chloride values ranged from 1.5 to $335 \mathrm{mg} / \mathrm{L}$, and sulfate values ranged from 0.4 to $63.4 \mathrm{mg} / \mathrm{L}$ (table 3 ). Bicarbonate values were calculated from the filtered acid-neutralizing capacity (alkalinity) concentrations, which are given in $\mathrm{mg} / \mathrm{L} \mathrm{CaCO}_{3}$, and are related to the "hardness" of the water. The chloride SMCL of $250 \mathrm{mg} / \mathrm{L}$ was exceeded in two samples, and the sulfate SMCL of $250 \mathrm{mg} / \mathrm{L}$ was not exceeded in any samples.

\section{Nutrients}

The predominant nutrient was nitrate (table 4). Nitrate concentrations ranged from 0.06 to $7.45 \mathrm{mg} / \mathrm{L}$ as $\mathrm{N}$, and the nitrate MCL of $10 \mathrm{mg} / \mathrm{L}$ as $\mathrm{N}$ was not exceeded in any samples. Samples from wells finished in sand and gravel had higher nitrate concentrations than those from wells finished in bedrock, except in the one bedrock well that had the highest nitrate concentration of any sample in this study. This well and the house it served were recently constructed, had an on-site septic system, and previous land use had been agricultural, with heavy use of manure as fertilizer.

\section{Metals and Radionuclides}

The most commonly detected metals and radionuclides were aluminum, barium, boron, iron, manganese, strontium, radon-222, and uranium (table 5). Aluminum was detected in 34 samples and concentrations ranged from 1 to 8,090 micrograms per liter $(\mu \mathrm{g} / \mathrm{L})$. The upper limit of the SMCL range for aluminum $(200 \mu \mathrm{g} / \mathrm{L})$ was exceeded in one sample, SB1066 (table 5). Barium was detected in all 39 samples, and concentrations ranged from 37 to $7,970 \mu \mathrm{g} / \mathrm{L}$. The MCL for barium $(2,000 \mu \mathrm{g} / \mathrm{L})$ was exceeded in one sample, SB1447, which was finished in bedrock (table 5). Iron was detected in 36 samples, and concentrations ranged from 20 to $5,980 \mu \mathrm{g} / \mathrm{L}$; the SMCL for iron $(300 \mu \mathrm{g} / \mathrm{L})$ was exceeded in 11 samples. Manganese was detected in 37 samples, and concentrations ranged from 1 to $681 \mu \mathrm{g} / \mathrm{L}$; the SMCL for manganese (50 $\mu \mathrm{g} / \mathrm{L}$ ) was exceeded in 20 samples. Uranium was detected in 
every sample; concentrations ranged from 0.007 to $1.17 \mu \mathrm{g} / \mathrm{L}$, but none exceeded the MCL of $30 \mu \mathrm{g} / \mathrm{L}$ (table 5).

Radon also was detected in every sample, and concentrations ranged from 100 to 2,580 picocuries per liter (pCi/L). The proposed MCL of $300 \mathrm{pCi} / \mathrm{L}$ for radon was exceeded in 34 samples, but the proposed ACML (Alternate Maximum Contaminant Level) of 4,000 pCi/L was not exceeded in any sample (table 5). The AMCL is the proposed allowable concentration of radon in a raw-water sample for a drinking-water system that has developed enhanced programs to address the health risks of radon in indoor air; none of the public-supply or private wells sampled had enhanced systems. The proposed MCL and AMCL for radon are still in the review process and have not been promulgated (U.S. Environmental Protection Agency, 2004).

Tritium is a hydrogen isotope that can indicate the general age of ground water. Tritium entered ground water during periods of atmospheric testing of nuclear devices that began in 1952 and peaked during the early 1960s (Clark and Fritz, 1997). Since then, tritium concentrations in precipitation and in ground water have been monitored, and the relative age of the ground water (time since it entered the ground water and stopped having contact with the atmosphere) can be estimated through a comparison of the of tritium concentration in a water sample with the recorded historical concentration in precipitation. The estimated age of a ground-water sample can reflect mixing of old and young water within an aquifer; however, the three ground-water samples with tritium values between 0 and 1 tritium units (TU) probably infiltrated into the aquifer before 1952 (table 5); samples with values between 1 and 4 TU are probably a mixture of recent (1952-2003) water with old (pre-1952); and samples with values between 5 and $15 \mathrm{TU}$ probably entered the aquifer after 1995 . None of the samples had values above $13 \mathrm{TU}$, but a value between 15 and $30 \mathrm{TU}$ would probably indicate water that infiltrated during the 1950s and 1960s, a value above 30 TU would indicate a large component of recharge from the 1960s and 1970s.

\section{Pesticides}

Samples for pesticide analysis were not collected at every site during this study because of limited funding. Previous studies have indicated a correlation between land use and well depth and concentrations of pesticides (Eckhardt and Stackelberg, 1995; Phillips and others, 1999; Eckhardt and others, 2001); therefore, most samples for pesticide analysis were collected at wells in areas dominated by agricultural or mixed land use (parks, highways, residential developments) and from relatively shallow wells finished in sand and gravel (table 6). Three samples were collected from bedrock wells, none of which was found to contain a pesticide.

All but one of the pesticides detected in this study (table 6) are herbicides that are used to control broadleaf weeds and undesirable grasses in agricultural fields, lawns, and other areas that require control of vegetation. Metalaxyl, a fungicide used to control fungus growth in vineyards and orchards, was detected only in two samples, and the concentrations were near the analytical detection limit. The herbicides detected most frequently were atrazine, deethylatrazine, and two degradation products of metolachlor, and these were only detected in wells finished in sand and gravel. Atrazine was detected in 11 samples; the concentrations ranged from 0.007 to $0.049 \mu \mathrm{g} / \mathrm{L}$ and did not exceed the MCL (3 $\mu \mathrm{g} / \mathrm{L}$ ) (U.S. Environmental Protection Agency, 1996). A degradation product of atrazinedeethylatrazine (2-chloro-4-isopropylamino-6-amino-striazine) - was detected in 10 samples (each of which also contained atrazine); concentrations ranged from 0.006 to 0.029 $\mu \mathrm{g} / \mathrm{L}$. Two degradation products of metolachlor (metolachlor ESA and metolachlor OA) were detected in 13 and 6 samples, respectively, and concentrations ranged from 0.05 to 1.49 $\mu \mathrm{g} / \mathrm{L}$ for metolachlor ESA and from 0.05 to $1.5 \mu \mathrm{g} / \mathrm{L}$ for metolachlor OA. No Federal MCLs currently have been established for deethylatrazine, metolachlor ESA, metolachlor OA; none of these pesticides concentrations exceeded the New York State MCLs, however (New York State Department of Environmental Conservation, 1998).

\section{Volatile Organic Compounds}

Volatile organic compounds (VOCs) were detected infrequently and at extremely low concentrations (table 7). Of the 11 VOCs detected during this study, 10 were detected in fewer than 4 samples each, and none of the concentrations exceeded MCLs. Trichloromethane was detected in 8 samples. Methyl tert-butyl ether (MTBE), a gasoline additive that can infiltrate into ground water from leaking gasoline-storage tanks, was detected in 2 samples at concentrations at or near the analytical detection limit. No MCL has been established for MTBE; however, the USEPA has suggested a limit of 20 to $40 \mu \mathrm{g} / \mathrm{L}$ on the basis of taste and odor of drinking water (U.S. Environmental Protection Agency, 1996).

\section{Bacteria}

All samples were analyzed for total coliform and fecal coliform (table 8). If a sample contained fecal coliform, it was also analyzed for Escherichia coli (E. coli). Total coliform were detected in 12 samples, fecal coliform in 7 samples, and E. coli in 6 samples. These samples were from wells finished in sand and gravel and bedrock. Most of the public-supply wells have chlorination systems that kill bacteria before the water is distributed to consumers; therefore, bacteria in the raw-water samples collected from the public-supply systems is not cause for concern. The samples from private residential wells had some of the highest concentrations of bacteria detected during this study, however; the owners of these wells were notified within 48 hours after sampling, and a full list of all the constituents for which the sample was analyzed was sent to each well owner upon completion of the project (2003). 


\section{Summary}

Water samples collected from 37 private and publicsupply wells during summer 2003 were analyzed to describe the chemical quality and physical properties of ground water throughout the Chemung River basin in New York. Samples were analyzed for physical properties, inorganic constituents, nutrients, metals, radionuclides, VOCs, pesticides, and bacteria. Of the 78 constituents that were detected, several exceeded Federal MCLs, SMCLs, and AMCLs.

The cations that were detected in the highest concentrations were calcium and sodium; the anions that were detected in the highest concentrations were bicarbonate, chloride, and sulfate. The predominant nutrient was nitrate. Two samples exceeded the chloride SMCL; 11 samples exceeded the sodium Drinking Water Advisory; none of the samples exceeded the MCL for nitrate.

The most commonly detected metals were aluminum, barium, iron, manganese, and strontium. The SMCL for aluminum was exceeded in one sample. The MCL for barium was exceeded in one sample; the SMCL for iron was exceeded in 11 samples; the SMCL for manganese was exceeded in 20 samples. Uranium was detected in every sample; no detections exceeded the MCL. Radon also was detected in every sample; the proposed MCL for radon was exceeded in 34 samples, but the proposed AMCL was not exceeded in any sample. The range of tritium values ( 0.6 to $12.5 \mathrm{TU})$ indicates that the water ranged from less than 10 years old to more than 50 years old.

All but one of the pesticides detected were herbicides; those detected most frequently were atrazine (detected in 11 samples), deethylatrazine (detected in 10 samples), metolachlor ESA (detected in 13 samples) and metolachlor OA (detected in 6 samples). Metolachlor ESA and OA were the pesticides detected at the highest concentrations. No Federal MCLs currently exist for deethylatrazine, metolachlor ESA, or metolachlor OA; the concentrations of these compounds did not exceed the New York State MCLs. Atrazine detections did not exceed Federal or New York State MCLs. Not every sample collected was analyzed for pesticides, and pesticides were detected only in wells finished in sand and gravel.

VOCs were detected in 15 samples, the concentrations were at or near the detection limits, and no sample exceeded an MCL. Bacteria were detected in water from bedrock as well as sand and gravel aquifers. Total coliform were detected in 12 samples; fecal coliform were detected in 7 samples; E. coli was detected in 6 samples.

\section{References Cited}

Cadwell, D.H., and others, 1991, Surficial geologic map of New York: New York State Museum-New York State Geological Survey, Map and Chart Series No. 40, 5 pls., $1: 250,000$.

Clark, I.D., and Fritz, Peter, 1997, Identifying and dating modern groundwaters, in Clark, I.D., and Fritz, Peter, eds., Environmental isotopes in hydrogeology: New York, Lewis Publishers, p. 172-196.

Eckhardt, D.A.V., and Stackelberg, P.E., 1995, Relation of ground-water quality to land use of Long Island, New York; Ground Water, V. 33, no. 6, p. 1019-1033.

Eckhardt, D.A.V., Hetcher, K.K., Phillips, P.J., and Miller, T.S., 2001, Pesticides and their metabolites in community water-supply wells of central and western New York, August 1999: U.S. Geological Survey Water-Resources Investigations Report 00-4128, 12 p.

Ferrer, Imma, Thurman, E.M., Barcelo, Damia, 1997, Identification of ionic chloroacetanilide herbicide metabolites in surface and groundwater by HPLC/MS using negative ionspray: Analytical Chemistry, v. 69, p. 4547-4553.

Meyer, M.T., Mills, M.S., and Thurman, E.M., 1993, Automated solid-phase extraction of herbicides from water for gas chromatographic-mass spectrometric analysis: Journal of Chromatography, v. 629, p. 55-59.

Miller, T.S., 1982, Elmira-Horseheads-Big Flats area, in Waller, R.M., and Finch, A.J., eds., Atlas of eleven selected aquifers in New York: U.S. Geological Survey, Open-File Report 82-553, p. 127-147.

New York State Department of Environmental Conservation, 1998, Water quality regulations for surface and groundwaters: Albany, N.Y., Title 6, chapter X (parts 703.5, table 1), 10 NYCRR Subpart 5-1, 4 p.

New York State Department of Health, 1998, New York State Health Department Public Water Systems Regulations [effective March 12, 1998]: Albany, N.Y.

Phillips, P.J., Eckhardt, D.A., Terracciano, S.A., and Rosenmann, L.R., 1999, Pesticides and their metabolites in wells of Suffolk County, New York, 1998; U.S. Geological Survey Water-Resources Investigations Report 99-4095, $12 \mathrm{p}$. 
Sandstrom, M.W., Stroppel, M.E., Foreman, W.T., and Schroeder, M.P., 2001, Methods of analysis by the U.S. Geological Survey National Water Quality LaboratoryDetermination of moderate-use pesticides and selected degradates in water by $\mathrm{C}-18$ solid-phase extraction and gas chromatography/mass spectrometry: U.S. Geological Survey Water-Resources Investigations Report 01-04098, $70 \mathrm{p}$.

Shelton, L.R., 1994, Field guide for collecting and processing stream-water samples for the National Water-Quality Assessment Program: U.S. Geological Survey Open-File Report 94-455, $42 \mathrm{p}$.

U.S. Environmental Protection Agency, 1996, Drinking water regulations and health advisories: Washington D.C., U.S. Environmental Protection Agency, Office of Water, EPA 822-B-96-002, Oct. 1996, 11 p.

U.S. Environmental Protection Agency, 1997, Guidelines for preparation of the comprehensive state water quality assessments (305(b) reports) and electronic updates: Washington D.C., U.S. Environmental Protection Agency, Office of Water, EPA 841-B-97-002A and EPA 841-B-97-002B, PL 95-217.
U.S. Environmental Protection Agency, 2002, Drinking water advisory-Consumer acceptability advice and health effects analysis on sodium: Washington D.C., U.S. Environmental Protection Agency, Office of Water, EPA 822-R-02-032, $34 \mathrm{p}$.

U.S. Environmental Protection Agency, 2004, Proposed radon in drinking water rule: Washington D.C., U.S. Environmental Protection Agency, Office of Water, http://www.epa.gov/safewater/radon/proposal.html, accessed May 14, 2004.

U.S. Geological Survey, variously dated, National field manual for the collection of water-quality data: U.S. Geological Survey Techniques of Water-Resources Investigations, book 9, chaps. A1-A9, available online at http://pubs.water.usgs. gov/twri9A. [Chapter updates and revisions are ongoing and are summarized at http://water.usgs.gov/owq/FieldManual/ mastererrata.html]

Zaugg, S.D., Sandstrom, M.W., Smith, S.G., and Fehlberg, K.M., 1995, Methods of analysis by the U.S. Geological Survey National Water Quality Laboratory - Determination of pesticides in water by $\mathrm{C}-18$ solid-phase extraction and capillary-column gas chromatography with selective-ion monitoring: U.S. Geological Survey Open-File Report 95-181, 49 p. 
Table 1. Well information and physical properties of ground-water samples from selected wells in the Chemung River basin, New York, 2003.

[mi, mile; mg/L, milligrams per liter; ${ }^{\circ} \mathrm{C}$, degrees Celsius; $\mu \mathrm{S} / \mathrm{cm}$, microsiemens per centimeter at $25^{\circ} \mathrm{C}$; 00080, National Water Information System (NWIS) Parameter Code.

Locations are shown shown in fig. 1.]

\begin{tabular}{|c|c|c|c|c|c|c|c|c|c|c|c|c|c|c|}
\hline \multirow[b]{2}{*}{$\begin{array}{c}\text { Well } \\
\text { number }\end{array}$} & \multirow[b]{2}{*}{$\begin{array}{l}\text { Date } \\
\text { Sampled } \\
\text { (all in } \\
\text { 2003) } \\
\end{array}$} & \multicolumn{5}{|c|}{ Well data } & \multirow[b]{2}{*}{$\begin{array}{l}\text { Dominant land } \\
\text { use within 0.5-mi } \\
\text { radius of well: } \\
\text { f, forested; } \\
\text { u, urban; } \\
\text { a, agricultural } \\
\text { or mixed } \\
\end{array}$} & \multicolumn{7}{|c|}{ Water data } \\
\hline & & $\begin{array}{l}\text { Type: } \\
\text { P, public } \\
\text { supply } \\
\text { R, private } \\
\text { residential }\end{array}$ & $\begin{array}{l}\quad \text { Location: } \\
\mathrm{U} \text {, uplands; } \\
\mathrm{V} \text {, main valley } \\
\text { of Chemung } \\
\text { River or trib. } \\
\text { valley }\end{array}$ & $\begin{array}{l}\text { Aquifer: } \\
\text { SG, sand } \\
\text { and gravel; } \\
\text { B, bedrock }\end{array}$ & $\begin{array}{c}\text { Depth } \\
\text { (feet below } \\
\text { land } \\
\text { surface) }\end{array}$ & $\begin{array}{c}\text { Casing } \\
\text { Length } \\
\text { (feet below } \\
\text { land surface) }\end{array}$ & & $\begin{array}{c}\text { Water } \\
\text { color, } \\
\text { filtered } \\
\text { (platinum } \\
\text { cobalt } \\
\text { units) } \\
00080\end{array}$ & $\begin{array}{l}\text { Dissolved- } \\
\text { oxygen } \\
\text { concentration, } \\
\text { unfiltered } \\
\text { (mg/L) } \\
00300\end{array}$ & $\begin{array}{c}\mathrm{pH}, \\
\text { field, } \\
\text {, unfiltered } \\
\text { (standard } \\
\text { units) } \\
00400\end{array}$ & $\begin{array}{l}\text { pH, } \\
\text { laboratory, c } \\
\text { unfiltered } \\
\text { (standard } \\
\text { units) } \\
00403 \\
\end{array}$ & $\begin{array}{c}\text { Specific } \\
\text { conductance, } \\
\text { unfiltered, } \\
\text { field } \\
(\mu \mathrm{S} / \mathrm{cm}) \\
00095 \\
\end{array}$ & $\begin{array}{c}\text { Specific } \\
\text { conductance, } \\
\text { unfiltered, } \\
\text { laboratory } \\
(\mu \mathrm{S} / \mathrm{cm}) \\
90095\end{array}$ & $\begin{array}{c}\text { Tempe } \\
\text { ature, } \\
\text { field } \\
\left({ }^{\circ} \mathrm{C}\right) \\
00010 \\
\end{array}$ \\
\hline CM 82 & $07-30$ & $\mathrm{P}$ & $\mathrm{V}$ & SG & 55 & 45 & $\mathrm{fu}$ & 5 & 8.2 & 8.0 & 7.7 & 1450 & 1420 & 11.0 \\
\hline CM 625 & $08-13$ & $\mathrm{P}$ & $\mathrm{V}$ & SG & 55 & 45 & fau & 5 & 2.7 & 8.0 & 7.8 & 440 & 449 & 11.3 \\
\hline CM 626 & $07-02$ & $\mathrm{P}$ & $\mathrm{V}$ & SG & 109.5 & 90 & fau & 2 & 3.0 & 8.2 & 7.5 & 1010 & 965 & 11.2 \\
\hline CM 627 & $08-06$ & $\mathrm{P}$ & $\mathrm{U}$ & SG & 56 & 47 & $\mathrm{fa}$ & 88 & 2.4 & 7.6 & 7.5 & 601 & 578 & 9.4 \\
\hline CM 628 & $07-22$ & $\mathrm{P}$ & $\mathrm{V}$ & SG & 72 & 62 & fau & 2 & 6.0 & 8.0 & 8.0 & 393 & 372 & 14.4 \\
\hline CM 629 & $07-23$ & $\mathrm{P}$ & $\mathrm{U}$ & B & 94 & 30 & $\mathrm{fa}$ & 12 & 0.4 & 8.0 & 7.6 & 1100 & 1060 & 10.9 \\
\hline CM 630 & $07-30$ & $\mathrm{P}$ & V & SG & 38.1 & 28 & $\mathrm{a}$ & $<1$ & 7.9 & 7.6 & 7.5 & 816 & 782 & 11.2 \\
\hline CM 631 & $07-10$ & $\mathrm{P}$ & $\mathrm{U}$ & $\mathrm{B}$ & 112 & 51 & $\mathrm{f}$ & 2 & 2.4 & 8.4 & 8.0 & 650 & 659 & 10.6 \\
\hline CM 632 & $07-30$ & $\mathrm{P}$ & V & SG & 51 & 20 & fau & 2 & 6.4 & 8.0 & 7.9 & 351 & 339 & 10.7 \\
\hline CM 633 & $08-06$ & $\mathrm{R}$ & $\mathrm{U}$ & $\mathrm{B}$ & 289 & 20 & $\mathrm{f}$ & 8 & 4.3 & 8.3 & 8.2 & 410 & 400 & 12.6 \\
\hline CM 634 & $07-31$ & $\mathrm{P}$ & $\mathrm{V}$ & SG & 75 & 69 & fau & 2 & 5.8 & 7.9 & 8.0 & 453 & 446 & 11.7 \\
\hline CM 635 & $08-12$ & $\mathrm{P}$ & $\mathrm{V}$ & SG & 47.3 & 30 & $\mathrm{u}$ & 2 & 5.4 & 7.8 & 7.5 & 419 & 413 & 16.1 \\
\hline CM 636 & $08-12$ & $\mathrm{P}$ & $\mathrm{V}$ & SG & 53.7 & 37 & $\mathrm{u}$ & 5 & 5.3 & 7.5 & 7.4 & 530 & 524 & 15.3 \\
\hline CM 637 & $08-12$ & $\mathrm{P}$ & $\mathrm{V}$ & SG & 75 & 55 & $\mathrm{u}$ & $<1$ & 6.4 & 7.8 & 7.5 & 750 & 748 & 12.0 \\
\hline CM 904 & 07-02 & $\mathrm{R}$ & $\mathrm{U}$ & B & 220 & 85.5 & fa & 18 & 0.2 & 7.9 & 7.5 & 690 & 621 & 11.5 \\
\hline CM 954 & 07-08 & $\mathrm{P}$ & V & B & 333 & 76 & fau & 5 & 6.7 & 8.2 & 8.0 & 460 & 424 & 11.3 \\
\hline SB 63 & $06-25$ & $\mathrm{P}$ & V & SG & 64 & 42 & $\mathrm{fu}$ & $<1$ & 5.5 & 7.4 & 7.2 & 898 & 872 & 12.0 \\
\hline SB 85 & $07-01$ & $\mathrm{P}$ & $\mathrm{V}$ & SG & 61 & 49 & fu & 5 & 4.1 & 8.1 & 7.8 & 709 & 688 & 11.8 \\
\hline SB 151 & $08-20$ & $\mathrm{P}$ & $\mathrm{V}$ & SG & 65 & 55 & $\mathrm{fu}$ & 12 & 4.4 & 7.5 & 7.2 & 1080 & 1100 & 11.0 \\
\hline SB 224 & $07-24$ & $\mathrm{P}$ & $\mathrm{V}$ & SG & 73 & 65 & fau & 2 & 6.1 & 8.1 & 7.9 & 850 & 792 & 10.6 \\
\hline SB 229 & 07-09 & $\mathrm{P}$ & $\mathrm{V}$ & SG & 96 & 86 & $\mathrm{fa}$ & 25 & 0.4 & 8.1 & 7.7 & 608 & 571 & 9.8 \\
\hline SB 380 & $06-25$ & $\mathrm{P}$ & $\mathrm{V}$ & SG & 60 & 56 & $\mathrm{u}$ & 2 & 6.6 & 7.5 & 7.2 & 586 & 566 & 11.0 \\
\hline SB 382 & 07-01 & $\mathrm{P}$ & V & SG & 75 & 67 & fu & 2 & 2.6 & 8.3 & 8.0 & 705 & 680 & 10.1 \\
\hline SB 390 & $07-24$ & $\mathrm{P}$ & $\mathrm{V}$ & SG & 63 & 53 & $\mathrm{fa}$ & 2 & 5.7 & 7.3 & 7.7 & 740 & 698 & 10.0 \\
\hline SB 391 & $08-20$ & $\mathrm{P}$ & $\mathrm{V}$ & SG & 98 & 83 & $\mathrm{fu}$ & 5 & 3.2 & 8.0 & 7.4 & 540 & 543 & 9.9 \\
\hline SB 392 & 09-03 & $\mathrm{P}$ & V & SG & 52 & 42 & fau & 5 & 7.5 & 8.4 & 7.4 & 719 & 710 & 9.9 \\
\hline SB1066 & $07-23$ & $\mathrm{R}$ & $\mathrm{U}$ & $\mathrm{B}$ & 181 & 90 & $\mathrm{f}$ & 200 & 7.2 & 7.3 & 7.6 & 204 & 211 & 13.6 \\
\hline SB1066 & 08-19 & $\mathrm{R}$ & $\mathrm{U}$ & B & 181 & 90 & $\mathrm{f}$ & 10 & 4.1 & 7.4 & 6.9 & 240 & 242 & 12.1 \\
\hline SB1077 & 07-09 & $\mathrm{R}$ & $\mathrm{U}$ & $\mathrm{B}$ & 105 & 37 & $\mathrm{f}$ & 2 & 8.3 & 7.8 & 7.7 & 260 & 286 & 8.6 \\
\hline SB1350 & $07-17$ & $\mathrm{R}$ & $\mathrm{U}$ & B & 140 & 47.5 & $\mathrm{f}$ & 20 & 0.2 & 8.1 & 7.6 & 520 & 490 & 9.9 \\
\hline SB1408 & $07-23$ & $\mathrm{R}$ & $\mathrm{U}$ & SG & 40 & 40 & $\mathrm{a}$ & 5 & 5.1 & 8.0 & 7.5 & 1280 & 1250 & 9.8 \\
\hline SB 1408 & 08-14 & $\mathrm{R}$ & $\mathrm{U}$ & SG & 40 & 40 & $\mathrm{a}$ & 8 & 3.4 & 7.8 & 7.6 & 1130 & 1120 & 11.4 \\
\hline SB1420 & 07-08 & $\mathrm{R}$ & $\mathrm{U}$ & B & 160 & 60.3 & $\mathrm{f}$ & 35 & 4.5 & 7.8 & 7.5 & 650 & 561 & 11.0 \\
\hline SB1447 & $07-10$ & $\mathrm{R}$ & $\mathrm{U}$ & B & 160 & 80.3 & $\mathrm{a}$ & 8 & 0.2 & 7.6 & 7.4 & 590 & 577 & 10.4 \\
\hline SB1451 & $07-16$ & $\mathrm{R}$ & $\mathrm{U}$ & SG & 30 & 30 & $\mathrm{f}$ & 2 & 1.0 & 8.0 & 7.7 & 385 & 357 & 9.4 \\
\hline SB1457 & $07-16$ & $\mathrm{R}$ & $\mathrm{U}$ & $\mathrm{B}$ & 120 & 88 & $\mathrm{fa}$ & 5 & 3.2 & 7.9 & 7.7 & 277 & 275 & 11.0 \\
\hline SB1470 & $06-26$ & $\mathrm{R}$ & $\mathrm{U}$ & $\mathrm{B}$ & 278 & 18 & $\mathrm{fa}$ & $<1$ & 5.4 & 8.4 & 7.5 & 374 & 371 & 11.2 \\
\hline SY 911 & 09-04 & $\mathrm{R}$ & $\mathrm{U}$ & B & 125 & 20 & $\mathrm{fa}$ & 5 & 1.4 & 8.3 & 8.0 & 969 & 884 & 12.8 \\
\hline SY1016 & $06-26$ & $\mathrm{R}$ & $\mathrm{V}$ & SG & 33.5 & 33.5 & $\mathrm{fa}$ & 25 & 0.4 & 9.0 & 7.6 & 575 & 559 & 10.1 \\
\hline
\end{tabular}

\footnotetext{
1 SB, Steuben County; CM, Chemung County; SY, Schuyler County; number is local well-identification number assigned by U.S. Geological Survey.
} 
Table 2. Constituents for which ground-water samples from the Chemung River basin, New York, were analyzed for but not detected, 2003.

\begin{tabular}{|c|c|c|}
\hline Elements & Diazinon 39572 & Methyl parathion 82667 \\
\hline Antimony 01097 & Dicamba 38442 & Methyl tert-pentyl ether 50005 \\
\hline Silver 01077 & 1,2-Dichlorobenzene 34536 & Metsulfuron 61697 \\
\hline Thallium 01059 & 1,3-Dichlorobenzene 34566 & Molinate 82671 \\
\hline Organic Compounds & 1,4-Dichlorobenzene 34571 & $m$-Xylene 85795 \\
\hline Acetochlor 49260 & Dichlorodifluoromethane 34668 & N-(4-Chlorophenyl-N'-methylurea) 61692 \\
\hline Acetochlor OA 61030 & 1,2-Dichloroethane 32103 & Napropamide 82684 \\
\hline Acetochlor SAA 62847 & 1,1-Dichloroethene 34501 & Neburon 49294 \\
\hline Acifluorfen 49315 & Dichloromethane 34423 & Nicosulfuron 50364 \\
\hline Alachlor 46342 & Dichloroprop 49302 & Norflurazon 49293 \\
\hline Alachlor SAA 62848 & 1,2-Dichloropropane 34541 & Oryzalin 49292 \\
\hline Aldicarb 49312 & Dieldrin 39381 & Oxamyl 38866 \\
\hline Aldicarb sulfone 49313 & Diethyl ether 81576 & $p, p^{\prime}-\mathrm{DDE} 34653$ \\
\hline Aldicarb sulfoxide 49314 & Diisopropyl ether 81577 & Parathion 39542 \\
\hline alpha-HCH 34253 & Dimethenamid ESA 61951 & Pebulate 82669 \\
\hline Azinphos-methyl 82686 & Dimethenamid OXA 62482 & Pendimethalin 82683 \\
\hline Bendiocarb 50299 & Dinoseb 49301 & Phenolic compounds 32730 \\
\hline Benfluralin 82673 & Diphenamid 04033 & Phorate 82664 \\
\hline Benomyl 50300 & Disulfoton 82677 & Picloram 49291 \\
\hline Bensulfuron 61693 & Diuron 49300 & Pronamide 82676 \\
\hline Bentazon 38711 & ЕРТC 82668 & Propachlor 04024 \\
\hline Benzene 34030 & Ethalfluralin 82663 & Propachlor ESA 62766 \\
\hline Bromacil 04029 & Ethoprop 82672 & Propachlor OXA 62767 \\
\hline Bromoxynil 49311 & Ethylbenzene 34371 & Propanil 82679 \\
\hline Butylate 04028 & Fenuron 49297 & Propargite 82685 \\
\hline Caffeine 50305 & Fipronil 62166 & Propham 49236 \\
\hline Carbaryl 49310 & Fipronil sulfide 62167 & Propiconazole 50471 \\
\hline Carbofuran 82674 & Fipronil sulfone 62168 & Propoxur 38538 \\
\hline Chloramben methyl ester 61188 & Flufenacet ESA 61952 & Siduron 38548 \\
\hline Chlorimuron 50306 & Flufenacet OXA 62483 & Simazine 04035 \\
\hline Chlorobenzene 34301 & Flumetsulam 61694 & Sulfometuron 50337 \\
\hline Chlorothalonil 49306 & Fluometuron 38811 & Syrene 77128 \\
\hline Chlorpyrifos 38933 & Fonofos 04095 & Tebuthiuron 82670 \\
\hline cis-Permethrin 82687 & 3-Hydroxycarbofuran 49308 & Terbacil 82665 \\
\hline Clopyralid 49305 & Imazaquin 50356 & Terbufos 82675 \\
\hline Cynazine 04041 & Imidacloprid 61695 & tert-Butyl ethyl ether 50004 \\
\hline Cycloate 04031 & 3-Ketocarbofuran 50295 & Tetrachloromethane 32102 \\
\hline 2,4-D 39732 & Lindane 39341 & Thiobencarb 82681 \\
\hline 2,4-DB 38746 & Linuron 38478 & trans-1,2-Dichloroethene 34546 \\
\hline 2,4-D methyl ester 50470 & Malathion 39532 & Triallate 82678 \\
\hline Dacthal monoacid 49304 & MCPA 38482 & Trichlorofluoromethane 34488 \\
\hline DCPA 82682 & MCPB 38487 & 1,1,2-Trichloro-1,2,2-trifluoromethane 77652 \\
\hline Desulfinyl fipronil 62170 & Methiocarb 38501 & Triclopyr 49235 \\
\hline \multirow[t]{2}{*}{ Desulfinyl fipronil amide 62169} & Methomyl 49296 & Trifuralin 82661 \\
\hline & & Vinyl chloride 39175 \\
\hline
\end{tabular}


Table 3. Concentrations of major inorganic constitutents in ground-water samples from the Chemung River basin, New York, 2003.

$\left[\mathrm{mg} / \mathrm{L}\right.$ as $\mathrm{CaCO}_{3}$, milligrams per liter as calcium carbonate; ${ }^{\circ} \mathrm{C}$, degrees Celsius. Locations are shown in fig. 1.]

\begin{tabular}{|c|c|c|c|c|c|c|c|c|c|c|c|c|}
\hline \multirow[b]{2}{*}{ Well no. ${ }^{1}$} & \multicolumn{2}{|c|}{$\begin{array}{c}\text { Acid-neutralizing capacity } \\
\text { fixed-endpoint (pH 4.5) titration } \\
\text { (mg/L as } \mathrm{CaCO}) \text { ) }\end{array}$} & \multirow[t]{2}{*}{$\begin{array}{c}\text { Bicarbonate }^{2} \\
\text { (mg/L as } \\
\left.\mathrm{HCO}_{3}\right)\end{array}$} & \multicolumn{8}{|c|}{ Concentrations in filtered samples, in milligrams per liter } & \multirow{2}{*}{$\begin{array}{c}\begin{array}{c}\text { Residue on } \\
\text { evaporation, } \\
\text { dried at } 180^{\circ} \mathrm{C} \\
(\mathrm{mg} / \mathrm{L}) \\
70300\end{array} \\
\end{array}$} \\
\hline & $\begin{array}{c}\text { Unfiltered } \\
90410\end{array}$ & $\begin{array}{c}\text { Filtered } \\
29801 \\
\end{array}$ & & $\begin{array}{l}\text { Calcium } \\
00915 \\
\end{array}$ & $\begin{array}{l}\text { Magnesium } \\
00925 \\
\end{array}$ & $\begin{array}{c}\text { Potassium } \\
00935 \\
\end{array}$ & $\begin{array}{l}\text { Sodium } \\
00930 \\
\end{array}$ & $\begin{array}{c}\text { Chloride } \\
00940 \\
\end{array}$ & $\begin{array}{c}\text { Fluoride } \\
00950 \\
\end{array}$ & $\begin{array}{r}\text { Silica } \\
00955 \\
\end{array}$ & $\begin{array}{l}\text { Sulfate } \\
00945\end{array}$ & \\
\hline CM 82 & 167 & 174 & 212 & 102 & 20.9 & 1.7 & 169 & 335 & $<.2$ & 7.98 & 20 & 812 \\
\hline CM 625 & 157 & 157 & 192 & 56.1 & 11.7 & 1.02 & 20.4 & 47.8 & $<.2$ & 8.67 & 8.7 & 271 \\
\hline CM 626 & 171 & 171 & 209 & 64.7 & 13 & 1.94 & 119 & 201 & $<.2$ & 11.4 & 13.6 & 562 \\
\hline CM 627 & 103 & 102 & 124 & 46.8 & 9.75 & 0.71 & 54.1 & 118 & $<.2$ & 9.81 & 11 & 357 \\
\hline CM 628 & 119 & 119 & 145 & 43 & 8.41 & 1.64 & 21.2 & 41.7 & $<.2$ & 5.54 & 15 & 224 \\
\hline CM 629 & 170 & 170 & 207 & 80.1 & 19.8 & 0.86 & 110 & 235 & $<.2$ & 12.3 & 13 & 642 \\
\hline CM 630 & 214 & 192 & 234 & 96.3 & 19 & 3.26 & 47.4 & 103 & $<.2$ & 10.2 & 27.9 & 466 \\
\hline CM 631 & 151 & 152 & 185 & 19.2 & 3.94 & 0.88 & 123 & 117 & 0.3 & 9.95 & 10.1 & 379 \\
\hline CM 632 & 115 & 115 & 140 & 48 & 10.3 & 1.1 & 9.14 & 19.2 & $<.2$ & 8.86 & 32.8 & 212 \\
\hline CM 633 & 198 & 197 & 240 & 16.2 & 3.36 & 0.58 & 76.9 & 4.4 & 0.2 & 10.6 & 20.7 & 258 \\
\hline CM 634 & 117 & 117 & 143 & 51.9 & 9.65 & 2.31 & 28.1 & 57.3 & $<.2$ & 6.8 & 22.4 & 252 \\
\hline CM 635 & 126 & 126 & 154 & 50.3 & 10.5 & 2.34 & 25.3 & 44.5 & $<.2$ & 6.67 & 19.8 & 241 \\
\hline CM 636 & 152 & 153 & 187 & 64.3 & 12.7 & 2.48 & 31.8 & 62.9 & $<.2$ & 7.83 & 24.1 & 299 \\
\hline CM 637 & 182 & 181 & 221 & 83.8 & 17.1 & 2.11 & 53.3 & 111 & $<.2$ & 9.37 & 30.6 & 426 \\
\hline CM 904 & 293 & 294 & 359 & 66.7 & 18 & 1.03 & 51.5 & 15.6 & $<.2$ & 16 & 38.8 & 386 \\
\hline CM 954 & 154 & 153 & 187 & 69.8 & 14 & 1.21 & 7.49 & 26.4 & $<.2$ & 15.1 & 46.2 & 272 \\
\hline SB 63 & 251 & 250 & 305 & 93.9 & 22.1 & 3.19 & 53.3 & 121 & $<.2$ & 10.6 & 30.2 & 498 \\
\hline SB 85 & 228 & 228 & 278 & 83.8 & 18.9 & 1.92 & 31.2 & 70.9 & $<.2$ & 12.3 & 35.5 & 431 \\
\hline SB 151 & 234 & 246 & 300 & 105 & 25.8 & 2.16 & 80.9 & 183 & 1.8 & 11 & 45.6 & 615 \\
\hline SB 224 & 232 & 238 & 290 & 71.8 & 18.2 & 4.53 & 72.2 & 98 & $<.2$ & 9.44 & 29.7 & 474 \\
\hline SB 229 & 190 & 190 & 232 & 68.2 & 17.7 & 1.26 & 32.8 & 62 & $<.2$ & 14.6 & 27.8 & 341 \\
\hline SB 380 & 153 & 153 & 187 & 61.1 & 13.8 & 2.33 & 38.7 & 76.6 & $<.2$ & 6.66 & 24.4 & 318 \\
\hline SB 382 & 173 & 173 & 211 & 72.8 & 13.8 & 2.22 & 43.8 & 102 & $<.2$ & 7.28 & 21.4 & 429 \\
\hline SB 390 & 193 & 254 & 310 & 103 & 24 & 1.62 & 18.3 & 37.6 & $<.2$ & 10.7 & 63.4 & 445 \\
\hline SB 391 & 175 & 178 & 217 & 67.4 & 15.8 & 1.84 & 23.9 & 55.1 & $<.2$ & 7.55 & 26 & 322 \\
\hline SB 392 & 183 & 186 & 227 & 81.7 & 21 & 1.39 & 25.2 & 74.7 & $<.2$ & 9.55 & 52.1 & 413 \\
\hline SB1066 & 89 & 88 & 107 & 32.8 & 5.55 & 0.92 & 4.12 & 3.66 & $<.2$ & 7.96 & 15.8 & 129 \\
\hline SB1066 & 110 & 110 & 134 & 36.3 & 6.3 & 0.96 & 3.94 & 2.37 & $<.2$ & 8.49 & 15.6 & 144 \\
\hline SB1077 & 135 & 132 & 161 & 42.5 & 11 & 1.11 & 4.68 & 1.46 & $<.2$ & 11.4 & 20.5 & 158 \\
\hline SB 1350 & 231 & 231 & 282 & 44.9 & 10.3 & 1.16 & 48 & 6.45 & 0.2 & 9.93 & 45.2 & 309 \\
\hline SB1408 & 211 & 211 & 257 & 97.2 & 19.6 & 7.28 & 133 & 255 & $<.2$ & 7.48 & 29.9 & 714 \\
\hline SB1408 & 215 & 215 & 262 & 89.6 & 18.8 & 7.18 & 118 & 223 & $<.2$ & 7.69 & 32 & 670 \\
\hline SB1420 & 188 & 189 & 231 & 37.8 & 9.26 & 1.52 & 80.7 & 86.1 & 0.3 & 11 & 0.4 & 339 \\
\hline SB1447 & 319 & 319 & 389 & 83.9 & 12.3 & 2.05 & 37.2 & 10 & $<.2$ & 16.3 & 2.4 & 353 \\
\hline SB1451 & 135 & 135 & 165 & 50.1 & 9.41 & 1.38 & 14.9 & 32.2 & $<.2$ & 6.3 & 12.2 & 204 \\
\hline SB1457 & 136 & 125 & 153 & 34.4 & 7.03 & 0.98 & 20 & 9.67 & $<.2$ & 10.1 & 7.5 & 153 \\
\hline SB1470 & 121 & 120 & 146 & 50.3 & 11.4 & 1.48 & 6.98 & 10.1 & $<.2$ & 13.3 & 24.1 & 217 \\
\hline SY 911 & 305 & 307 & 375 & 8.58 & 1.78 & 0.75 & 173 & 115 & 1.3 & 7.07 & 2 & 529 \\
\hline SY1016 & 235 & 245 & 299 & 81.1 & 22.4 & 0.95 & 7.19 & 24.3 & $<.2$ & 14.5 & 28.7 & 327 \\
\hline
\end{tabular}

${ }^{1}$ SB, Steuben County; CM, Chemung County; SY, Schuyler County. Number is local well-identification number assigned by U.S. Geological Survey.

${ }^{2}$ Calculated from filtered acid-neutralizing capacity concentrations. 
Table 4. Concentrations of nutrients in ground-water samples from the Chemung River basin, New York, 2003.

[mg/L, milligrams per liter; $\mathrm{N}$, nitrogen; $\mathrm{P}$, phosphorus. Locations are shown in fig. 1.]

\begin{tabular}{|c|c|c|c|c|c|c|c|}
\hline $\begin{array}{l}\text { Station } \\
\text { name }^{1} \\
\end{array}$ & $\begin{array}{l}\text { Ammonia plus } \\
\text { organic nitrogen, } \\
\text { filtered } \\
\text { (mg/L as } \mathrm{N} \text { ) } \\
00623 \\
\end{array}$ & $\begin{array}{l}\text { Ammonia, } \\
\text { filtered } \\
\text { (mg/L as N) } \\
00608\end{array}$ & $\begin{array}{l}\text { Nitrite plus } \\
\text { nitrate, filtered } \\
\text { (mg/L as } \mathrm{N} \\
\text { 00631) }\end{array}$ & $\begin{array}{l}\text { Nitrite, } \\
\text { filtered } \\
\text { (mg/L as N) } \\
00613 \\
\end{array}$ & $\begin{array}{l}\text { Nitrate, } \\
\text { filtered } \\
\text { (mg/L as N) } \\
00631-00613 \\
\end{array}$ & $\begin{array}{l}\text { Orthophosphate, } \\
\text { filtered } \\
\text { (mg/L as N) } \\
00671\end{array}$ & $\begin{array}{l}\text { Organic } \\
\text { carbon, } \\
\text { unfiltered } \\
\text { (mg/L as } \mathrm{N} \text { ) } \\
00680 \\
\end{array}$ \\
\hline CM 82 & $<.10$ & $<.04$ & 1.12 & $<.008$ & 1.12 & $<.02$ & 1.5 \\
\hline CM 625 & $<.10$ & ${ }^{\mathrm{E}} .02$ & 0.06 & $<.008$ & 0.06 & $<.18$ & 1.3 \\
\hline CM 626 & 0.16 & 0.17 & $<.06$ & $<.008$ & $<.06$ & $<.02$ & 1.2 \\
\hline CM 627 & $<.10$ & $<.04$ & $<.06$ & $<.008$ & $<.06$ & $<.02$ & 1.1 \\
\hline CM 628 & E.07 & $<.04$ & 0.23 & $<.008$ & 0.23 & $<.02$ & 1.4 \\
\hline CM 629 & 0.27 & 0.23 & $<.06$ & $<.008$ & $<.06$ & 0.04 & 0.8 \\
\hline CM 630 & ${ }^{\mathrm{E}} .05$ & $<.04$ & 5.99 & $<.008$ & 5.99 & $<.02$ & 1.5 \\
\hline CM 631 & 0.28 & 0.24 & $<.06$ & $<.008$ & $<.06$ & 0.02 & 0.6 \\
\hline CM 632 & $<.10$ & $<.04$ & 1.03 & $<.008$ & 1.03 & $<.02$ & 1.8 \\
\hline CM 633 & $<.10$ & $<.04$ & 0.22 & $<.008$ & 0.22 & 0.02 & 3.1 \\
\hline CM 634 & $<.10$ & $<.04$ & 0.92 & $<.008$ & 0.92 & $<.02$ & 1.7 \\
\hline CM 635 & 0.14 & $<.04$ & 0.64 & $<.008$ & 0.64 & 0.02 & 2.4 \\
\hline CM 636 & 0.2 & 0.09 & 0.96 & $<.008$ & 0.96 & $<.02$ & 2.3 \\
\hline CM 637 & ${ }^{\mathrm{E}} .08$ & $<.04$ & 2.69 & $<.008$ & 2.69 & $<.02$ & 2.7 \\
\hline CM 904 & 0.2 & 0.22 & $<.06$ & $<.008$ & $<.06$ & $<.02$ & 2.6 \\
\hline CM 954 & ${ }^{\mathrm{E}} .05$ & 0.04 & $<.06$ & $<.008$ & $<.06$ & $<.02$ & 0.7 \\
\hline SB 63 & $<.10$ & $<.04$ & 1.81 & $<.008$ & 1.81 & $<.02$ & 1.1 \\
\hline SB 85 & ${ }^{\mathrm{E}} .07$ & $<.04$ & $<.06$ & $<.008$ & $<.06$ & $<.02$ & 1.3 \\
\hline SB 151 & $<.10$ & $<.04$ & 0.54 & $<.008$ & 0.54 & $<.02$ & 2.6 \\
\hline SB 224 & ${ }^{\mathrm{E}} .06$ & $<.04$ & 5.21 & $<.008$ & 5.21 & $<.02$ & 1.4 \\
\hline SB 229 & 0.14 & 0.08 & $<.06$ & $<.008$ & $<.06$ & $<.02$ & 1.2 \\
\hline SB 380 & $<.10$ & $<.04$ & 0.99 & $<.008$ & 0.99 & $<.02$ & 1.1 \\
\hline SB 382 & ${ }^{\mathrm{E}} .07$ & $<.04$ & 1.63 & $<.008$ & 1.63 & $<.02$ & 2 \\
\hline SB 390 & ${ }^{\mathrm{E}} .05$ & $<.04$ & 3.95 & $<.008$ & 3.95 & $<.02$ & 1 \\
\hline SB 391 & $<.10$ & $<.04$ & 1.14 & $<.008$ & 1.14 & $<.02$ & 5.9 \\
\hline SB 392 & ${ }^{\mathrm{E}} .06$ & $<.04$ & 0.58 & 0.013 & 0.567 & $<.02$ & 1.4 \\
\hline SB1066 & 0.11 & $<.04$ & 0.26 & $<.008$ & 0.26 & $<.02$ & 2.9 \\
\hline SB1066 & $<.10$ & $<.04$ & 0.15 & $<.008$ & 0.15 & $<.02$ & 1.1 \\
\hline SB1077 & $<.10$ & $<.04$ & ${ }^{\mathrm{E}} .03$ & $<.008$ & ${ }^{\mathrm{E}} .03$ & $<.02$ & 1 \\
\hline SB1350 & $<.10$ & 0.08 & $<.06$ & $<.008$ & $<.06$ & $<.02$ & 1 \\
\hline SB1408 & 0.2 & $<.04$ & 3.05 & $<.008$ & 3.05 & ${ }^{\mathrm{E}} .01$ & 2.4 \\
\hline SB1408 & 0.13 & $<.04$ & 1.98 & 0.009 & 1.971 & $<.18$ & 1.9 \\
\hline SB1420 & 0.35 & 0.33 & $<.06$ & $<.008$ & $<.06$ & 0.05 & 1.1 \\
\hline SB1447 & 0.22 & 0.2 & $<.06$ & $<.008$ & $<.06$ & $<.02$ & 1.4 \\
\hline SB1451 & $<.10$ & $<.04$ & 0.63 & $<.008$ & 0.63 & $<.02$ & 2.7 \\
\hline SB1457 & $<.10$ & $<.04$ & $<.06$ & $<.008$ & $<.06$ & $<.02$ & 1.2 \\
\hline SB1470 & 0.1 & $<.04$ & 7.45 & $<.008$ & 7.45 & $<.02$ & 1.2 \\
\hline SY 911 & 0.42 & 0.33 & $<.06$ & $<.008$ & $<.06$ & 0.03 & 1.4 \\
\hline SY1016 & $<.10$ & $<.04$ & $<.06$ & $<.008$ & $<.06$ & $<.02$ & 9.3 \\
\hline
\end{tabular}

${ }^{1}$ SB, Steuben County; CM, Chemung County; SY, Schuyler County. Number is local well-identification number assigned by U.S. Geological Survey.

${ }^{\mathrm{E}}$ estimated value; constituent was detected in the sample below the laboratory reporting level. 
Table 5. Concentrations of metals and radionuclides in ground-water samples from the Chemung River basin, New York, 2003.

[All values are in micrograms per liter except as noted. Locations are shown in fig. 1.]

\begin{tabular}{|c|c|c|c|c|c|c|c|c|c|c|c|c|}
\hline Well no. ${ }^{1}$ & $\begin{array}{c}\text { Aluminum, } \\
\text { unfiltered, } \\
\text { recoverable } \\
01105\end{array}$ & $\begin{array}{c}\text { Barium, } \\
\text { unfiltered, } \\
\text { recoverable } \\
01007\end{array}$ & $\begin{array}{c}\text { Beryllium, } \\
\text { unfiltered, } \\
\text { recoverable } \\
01012\end{array}$ & $\begin{array}{l}\text { Boron, } \\
\text { filtered } \\
01020\end{array}$ & $\begin{array}{c}\text { Cadmium, } \\
\text { unfiltered } \\
01027\end{array}$ & $\begin{array}{c}\text { Chromium, } \\
\text { unfiltered, } \\
\text { recoverable } \\
01034\end{array}$ & $\begin{array}{c}\text { Cobalt, } \\
\text { unfiltered, } \\
\text { recoverable } \\
01037\end{array}$ & $\begin{array}{c}\text { Copper, } \\
\text { unfiltered, } \\
\text { recoverable } \\
01042\end{array}$ & $\begin{array}{l}\text { Iron, } \\
\text { filtered } \\
01046\end{array}$ & $\begin{array}{c}\text { Iron, } \\
\text { unfiltered, } \\
\text { recoverable } \\
01045\end{array}$ & $\begin{array}{c}\text { Lead, } \\
\text { unfiltered, } \\
\text { recoverable } \\
01051\end{array}$ & $\begin{array}{c}\text { Lithium, } \\
\text { unfiltered, } \\
\text { recoverable } \\
01132\end{array}$ \\
\hline SB 63 & $<2$ & 278 & $<.06$ & 100 & $<.04$ & $<.8$ & $\mathrm{~m}$ & 2.1 & $<8$ & $<6$ & $\mathrm{~m}$ & 4.6 \\
\hline CM 82 & 16 & 220 & $<.06$ & 50 & $<.04$ & ${ }^{\mathrm{E}} .6$ & $\mathrm{~m}$ & 1.6 & $<8$ & 30 & $\mathrm{~m}$ & 5.5 \\
\hline CM 625 & $\mathrm{E}_{2}$ & 280 & $<.06$ & 40 & $<.04$ & $<.8$ & $\mathrm{~m}$ & $\mathrm{E}_{.4}$ & 317 & 290 & $\mathrm{~m}$ & 6.8 \\
\hline CM 626 & 3 & 155 & $<.06$ & 80 & $<.04$ & $<.8$ & $\mathrm{~m}$ & 1.3 & 11 & 20 & $\mathrm{~m}$ & 8.6 \\
\hline CM 627 & 23 & 900 & $<.06$ & 40 & $<.04$ & $<.8$ & $\mathrm{~m}$ & 2.5 & 26 & 1020 & 8 & 9 \\
\hline CM 628 & 4 & 129 & $<.06$ & 20 & $<.04$ & $<.8$ & $\mathrm{~m}$ & 1.3 & $<8$ & $<6$ & $\mathrm{~m}$ & 1.2 \\
\hline CM 629 & $\mathrm{E}_{1}$ & 446 & $<.06$ & 210 & $<.04$ & $<.8$ & $\mathrm{~m}$ & 1.5 & 316 & 330 & $\mathrm{~m}$ & 34.3 \\
\hline CM 630 & $<2$ & 169 & $<.06$ & 50 & $<.04$ & $<.8$ & $\mathrm{~m}$ & 0.6 & $<8$ & $<6$ & $<.06$ & 4.4 \\
\hline CM 631 & 116 & 197 & $<.06$ & 190 & $<.04$ & $<.8$ & $\mathrm{~m}$ & $\mathrm{E}_{.4}$ & $<8$ & 320 & $\mathrm{~m}$ & 45.9 \\
\hline CM 632 & $\mathrm{E}_{2}$ & 121 & $<.06$ & 10 & $<.04$ & $<.8$ & $\mathrm{~m}$ & $<.6$ & $<8$ & $\mathrm{~m}$ & $<.06$ & 4.5 \\
\hline CM 633 & 83 & 108 & $<.06$ & 240 & $<.04$ & $<.8$ & $\mathrm{~m}$ & 3.8 & $<8$ & 140 & $\mathrm{~m}$ & 32.1 \\
\hline CM 634 & 5 & 67 & $<.06$ & 30 & $<.04$ & $<.8$ & $\mathrm{~m}$ & 32.3 & 31 & 70 & $\mathrm{~m}$ & 2.1 \\
\hline CM 635 & 3 & 93 & $<.06$ & 50 & $<.04$ & $<.8$ & $\mathrm{~m}$ & 13 & $<8$ & $\mathrm{~m}$ & $\mathrm{~m}$ & 3.1 \\
\hline CM 636 & 3 & 134 & $<.06$ & 50 & $<.04$ & $<.8$ & $\mathrm{~m}$ & 5.4 & $\mathrm{E}_{5}$ & $\mathrm{~m}$ & $\mathrm{~m}$ & 3.1 \\
\hline CM 637 & $\mathrm{E}_{2}$ & 156 & $<.06$ & 60 & $<.04$ & $<.8$ & $\mathrm{~m}$ & 3.3 & $<8$ & $\mathrm{~m}$ & $\mathrm{~m}$ & 6.8 \\
\hline CM 904 & 64 & 93 & $<.06$ & 110 & $<.04$ & 1.1 & $\mathrm{~m}$ & 1 & 527 & 670 & $\mathrm{~m}$ & 77.9 \\
\hline CM 954 & $\mathrm{E}_{1}$ & 122 & $<.06$ & 20 & $<.04$ & $<.8$ & $\mathrm{~m}$ & 0.6 & 197 & 260 & $\mathrm{~m}$ & 7.6 \\
\hline SB 85 & 9 & 426 & $<.06$ & 80 & $<.04$ & $<.8$ & $\mathrm{~m}$ & 1.1 & 16 & 30 & $\mathrm{~m}$ & 7 \\
\hline SB 151 & $\mathrm{E}_{2}$ & 215 & $<.06$ & 20 & $<.04$ & $<.8$ & $\mathrm{~m}$ & 4.5 & 20 & 30 & $<.06$ & 10.1 \\
\hline SB 224 & $<2$ & 165 & $<.06$ & 30 & $<.04$ & $<.8$ & $\mathrm{~m}$ & 3.6 & $<8$ & $<6$ & $<.06$ & 5 \\
\hline SB 229 & $\mathrm{E}_{1}$ & 247 & $<.06$ & 40 & ${ }^{\mathrm{E}} .02$ & $<.8$ & $\mathrm{~m}$ & ${ }^{\mathrm{E}} .5$ & 588 & 530 & $\mathrm{~m}$ & 11.2 \\
\hline SB 380 & $E_{2}$ & 100 & $<.06$ & 290 & $<.04$ & $<.8$ & $\mathrm{~m}$ & 2.1 & $<8$ & $<6$ & $\mathrm{~m}$ & 3.4 \\
\hline SB 382 & $<2$ & 147 & $<.06$ & 460 & $<.04$ & $<.8$ & $\mathrm{~m}$ & 3.3 & $<8$ & $\mathrm{~m}$ & $\mathrm{~m}$ & 3.3 \\
\hline SB 390 & $<2$ & 112 & $<.06$ & 10 & $<.04$ & $<.8$ & $\mathrm{~m}$ & 1.1 & $<8$ & $\mathrm{~m}$ & $\mathrm{~m}$ & 9.6 \\
\hline SB 391 & $\mathrm{E}_{1}$ & 151 & $<.06$ & 20 & $<.04$ & $<.8$ & $\mathrm{~m}$ & 1.7 & $<8$ & $\mathrm{~m}$ & $<.06$ & 3.1 \\
\hline SB 392 & $\mathrm{E}_{1}$ & 149 & $<.06$ & 20 & $<.04$ & $<.8$ & $\mathrm{~m}$ & 2.1 & $<8$ & 30 & $\mathrm{~m}$ & 5.1 \\
\hline SB1066 & 8090 & 212 & 0.22 & 20 & ${ }^{\mathrm{E}} .03$ & 3.7 & 2 & 64.3 & $<8$ & 5980 & 3 & 10.8 \\
\hline SB1066 & 72 & 169 & $<.06$ & 20 & $<.04$ & $<.8$ & $\mathrm{~m}$ & 38.1 & $<8$ & 270 & $\mathrm{~m}$ & 5.7 \\
\hline SB1077 & 134 & 81 & $<.06$ & 20 & $<.04$ & $<.8$ & $\mathrm{~m}$ & 0.9 & $<8$ & 320 & $\mathrm{~m}$ & 9.9 \\
\hline SB1350 & 22 & 110 & $<.06$ & 160 & $<.04$ & E.5 & $\mathrm{m}$ & 1.3 & 803 & 1220 & $\mathrm{~m}$ & 21.7 \\
\hline SB1408 & 8 & 320 & $<.06$ & 40 & $<.04$ & $<.8$ & $\mathrm{~m}$ & 2.5 & 20 & 80 & $<.06$ & 4.4 \\
\hline SB1408 & 4 & 296 & $<.06$ & 40 & $<.04$ & $<.8$ & $\mathrm{~m}$ & 2.5 & 13 & 190 & $\mathrm{~m}$ & 5.2 \\
\hline SB1420 & 22 & 406 & $<.06$ & 140 & $<.04$ & $<.8$ & $\mathrm{~m}$ & E. 6 & 1510 & 1530 & 3 & 25.7 \\
\hline SB1447 & 4 & 7970 & $<.06$ & 140 & $<.04$ & $<.8$ & $\mathrm{~m}$ & 1.4 & 339 & 320 & $\mathrm{~m}$ & 26.7 \\
\hline SB1451 & 33 & 37 & $<.06$ & 10 & $<.04$ & $<.8$ & $\mathrm{~m}$ & 4.8 & $<8$ & 100 & $\mathrm{~m}$ & 2 \\
\hline SB1457 & 4 & 128 & $<.06$ & 80 & $<.04$ & $<.8$ & $\mathrm{~m}$ & $<.6$ & $\mathrm{E}_{7}$ & 50 & $\mathrm{~m}$ & 8.7 \\
\hline SB1470 & 4 & 77 & $<.06$ & 30 & $<.04$ & $<.8$ & $\mathrm{~m}$ & 18.6 & $<8$ & $\mathrm{~m}$ & $\mathrm{~m}$ & 11.5 \\
\hline SY 911 & 79 & 233 & $<.06$ & 430 & $<.04$ & $<.8$ & $\mathrm{~m}$ & $<.6$ & ${ }^{\mathrm{E}_{6}}$ & 150 & $\mathrm{~m}$ & 93.9 \\
\hline SY1016 & 6 & 551 & $<.06$ & 20 & $<.04$ & $<.8$ & $\mathrm{~m}$ & 0.9 & 953 & 940 & $\mathrm{~m}$ & 8.8 \\
\hline
\end{tabular}

\footnotetext{
1 SB, Steuben County; CM, Chemung County; SY, Schuyler County. Number is local well-identification number assigned by U.S. Geological Survey.

E estimated value; constituent was detected in the sample below the laboratory reporting level.

$\mathrm{m}$ constituent was detected in the sample but was not quantified.
} 
Table 5. Concentrations of metals and radionuclides in ground-water samples from the Chemung River basin, New York, 2003 (continued).

\begin{tabular}{|c|c|c|c|c|c|c|c|c|c|c|c|}
\hline Well no. ${ }^{1}$ & $\begin{array}{c}\text { Manganese, } \\
\text { filtered } \\
01056 \\
\end{array}$ & $\begin{array}{c}\text { Manganese, } \\
\text { unfiltered, } \\
\text { recoverable } \\
01055 \\
\end{array}$ & $\begin{array}{c}\text { Mercury, } \\
\text { unfiltered, } \\
\text { recoverable } \\
71900 \\
\end{array}$ & $\begin{array}{c}\text { Molybdenum } \\
\text { unfiltered, } \\
\text { recoverable } \\
01062 \\
\end{array}$ & $\begin{array}{c}\text { Nickel, } \\
\text { unfiltered, } \\
\text { recoverable } \\
01067 \\
\end{array}$ & $\begin{array}{c}\text { Selenium, } \\
\text { unfiltered, } \\
\text { recoverable } \\
01147 \\
\end{array}$ & $\begin{array}{c}\text { Strontium, } \\
\text { unfiltered, } \\
\text { recoverable } \\
01082 \\
\end{array}$ & $\begin{array}{c}\text { Radon-222, } \\
\text { unfiltered, } \\
\text { picocuries } \\
\text { per liter } \\
82303 \\
\end{array}$ & $\begin{array}{c}\text { Tritium, } \\
\text { unfiltered } \\
\text { (tritium units) } \\
07000\end{array}$ & $\begin{array}{c}\text { Uranium } \\
\text { (natural), } \\
\text { unfiltered } \\
28011 \\
\end{array}$ & $\begin{array}{c}\text { Zinc, } \\
\text { unfiltered, } \\
\text { recoverable } \\
01092 \\
\end{array}$ \\
\hline SB 63 & 4.9 & 5 & $<.02$ & $<.2$ & 3 & $\mathrm{E}_{0.3}$ & 145 & 630 & 9.5 & 0.284 & 3 \\
\hline CM 82 & 0.6 & 1 & $<.02$ & $\mathrm{E}_{.1}$ & 2 & $<.5$ & 142 & 950 & 10.7 & 0.281 & 3 \\
\hline CM 625 & 278 & 253 & $<.02$ & 0.8 & 2 & $\mathrm{E}_{.4}$ & 182 & 570 & 9.4 & 0.301 & 3 \\
\hline CM 626 & 439 & 414 & $<.02$ & 0.9 & 2 & 0.8 & 497 & 540 & 4.1 & 0.606 & 3 \\
\hline CM 627 & 293 & 504 & $<.02$ & 0.2 & 2 & 1 & 533 & 390 & 8.8 & ${ }^{\mathrm{E}} .010$ & 19 \\
\hline CM 628 & $<.4$ & $<.22$ & $<.02$ & $\mathrm{E}_{.1}$ & 1 & $<.5$ & 95 & 570 & 11.3 & 0.138 & 6 \\
\hline CM 629 & 383 & 388 & $<.02$ & 0.3 & 2 & 0.8 & 1400 & 810 & 0.6 & 0.156 & $<2$ \\
\hline CM 630 & ${ }^{\mathrm{E}_{4}}$ & $\mathrm{~m}$ & $<.02$ & $<.2$ & 2 & $\mathrm{E}_{.4}$ & 123 & 760 & 12.2 & 0.202 & $\mathrm{E}_{1}$ \\
\hline CM 631 & 86.8 & 86 & $<.02$ & 0.6 & $\mathrm{~m}$ & $<.5$ & 308 & 160 & 5.3 & 0.087 & 2 \\
\hline CM 632 & $<.4$ & $\mathrm{M}$ & $<.02$ & $\mathrm{E}_{.1}$ & $\mathrm{~m}$ & E. 3 & 87.9 & 580 & 10.0 & 0.205 & $<2$ \\
\hline CM 633 & 0.8 & 20 & $<.02$ & 0.2 & $\mathrm{~m}$ & $\mathrm{E}_{.3}$ & 218 & 300 & 2.5 & 0.036 & $\mathrm{E}_{2}$ \\
\hline CM 634 & 1.4 & 2 & $<.02$ & $<.2$ & 1 & $<.5$ & 71.1 & 670 & 10.3 & 0.088 & $<2$ \\
\hline CM 635 & 91.1 & 78.9 & $<.02$ & 0.5 & 2 & 0.6 & 70.4 & 840 & 11.6 & 0.098 & 9 \\
\hline CM 636 & 801 & 681 & $<.02$ & 0.7 & 5 & 0.8 & 88.3 & 740 & 11.0 & 0.146 & 7 \\
\hline CM 637 & 3.4 & 3 & $<.02$ & ${ }^{\mathrm{E}} .2$ & 3 & 0.9 & 98 & 750 & 10.0 & 0.22 & 18 \\
\hline CM 904 & 215 & 157 & $<.02$ & ${ }^{\mathrm{E}} .1$ & 2 & $<.5$ & 674 & 450 & $\mathrm{~m}$ & 0.03 & 17 \\
\hline CM 954 & 271 & 261 & $<.02$ & 0.3 & 1 & $<.5$ & 266 & 100 & 8.8 & 0.097 & 80 \\
\hline SB 85 & 328 & 317 & $<.02$ & 0.3 & 2 & $<.5$ & 175 & 1700 & 9.7 & 1.17 & $<2$ \\
\hline SB 151 & 24.2 & 24 & $<.02$ & 0.4 & 3 & $<.5$ & 175 & 760 & 11.6 & 0.955 & $<2$ \\
\hline SB 224 & $\mathrm{E}_{.4}$ & $<.22$ & $<.02$ & 0.3 & 2 & $<.5$ & 95.4 & 760 & 11.3 & 0.29 & 5 \\
\hline SB 229 & 233 & 225 & $<.02$ & 4.7 & 1 & $<.5$ & 279 & 250 & 11.6 & 0.6 & $<2$ \\
\hline SB 380 & $<.4$ & $\mathrm{~m}$ & $<.02$ & 0.2 & 1 & 0.9 & 85.4 & 730 & 10.9 & 0.172 & 3 \\
\hline SB 382 & $<.4$ & $\mathrm{~m}$ & $<.02$ & $<.2$ & 2 & $\mathrm{E}_{.4}$ & 108 & 550 & 10.0 & 0.127 & 5 \\
\hline SB 390 & 1 & $\mathrm{~m}$ & $<.02$ & 1.6 & 3 & ${ }^{\mathrm{E}} .3$ & 166 & 490 & 12.5 & 0.509 & 3 \\
\hline SB 391 & 26.2 & 27 & $<.02$ & 0.4 & 2 & ${ }^{\mathrm{E}} .3$ & 101 & 610 & 11.9 & 0.322 & 14 \\
\hline SB 392 & 139 & 137 & $<.02$ & ${ }^{\mathrm{E}} .2$ & 2 & 0.5 & 117 & 490 & 12.5 & 0.373 & $<2$ \\
\hline SB1066 & 0.8 & 50 & ${ }^{\mathrm{E}} .01$ & ${ }^{\mathrm{E}} .1$ & 7 & $<.5$ & 70.6 & 1010 & 11.0 & 0.311 & 40 \\
\hline SB1066 & 2.5 & 5 & $<.02$ & ${ }^{\mathrm{E}} .2$ & 1 & $\mathrm{E}_{.3}$ & 87.1 & 1580 & 11.0 & 0.36 & 13 \\
\hline SB1077 & $<.4$ & 320 & $<.02$ & ${ }^{\mathrm{E}} .1$ & 1 & $<.5$ & 83.3 & 2180 & 7.8 & 0.281 & 13 \\
\hline SB1350 & 469 & 454 & $<.02$ & 0.8 & 1 & $<.5$ & 180 & 1540 & 0.6 & 1.01 & 2 \\
\hline SB1408 & 3.9 & 4 & $<.02$ & $\mathrm{E}_{.1}$ & 3 & $\mathrm{E}_{.4}$ & 120 & 1140 & 12.9 & 0.642 & 5 \\
\hline SB1408 & 7.8 & 36.5 & $<.02$ & $\mathrm{E}_{.1}$ & 4 & $\mathrm{E}_{.4}$ & 111 & 630 & 13.5 & 0.862 & 22 \\
\hline SB1420 & 371 & 367 & $<.02$ & 1.8 & 1 & ${ }^{\mathrm{E}} .5$ & 853 & 520 & 2.5 & 0.029 & 28 \\
\hline SB1447 & 360 & 342 & $<.02$ & E.1 & 1 & $<.5$ & 897 & 2130 & $\mathrm{~m}$ & 0.171 & 151 \\
\hline SB1451 & 2.1 & 3 & $<.02$ & ${ }^{\mathrm{E}} .2$ & 1 & $\mathrm{E}_{.3}$ & 65.6 & 1030 & 11.3 & 0.119 & 60 \\
\hline SB1457 & 99.5 & 85.1 & $<.02$ & 1.6 & $\mathrm{~m}$ & $<.5$ & 115 & 2420 & 3.1 & 0.587 & 3 \\
\hline SB1470 & 4.2 & 5 & $<.02$ & $\mathrm{E}_{.2}$ & 2 & $<.5$ & 273 & 2580 & 6.3 & 0.102 & 3 \\
\hline SY 911 & 13 & 15 & $<.02$ & $<.2$ & $\mathrm{~m}$ & 0.8 & 370 & & 1.3 & ${ }^{\mathrm{E}} .007$ & 5 \\
\hline SY1016 & 133 & 115 & $<.02$ & 1.5 & 2 & $<.5$ & 219 & 210 & 10.1 & 0.292 & $<2$ \\
\hline
\end{tabular}

1 SB, Steuben County; CM, Chemung County; SY, Schuyler County. Number is local well-identification number assigned by U.S. Geological Survey.

$\mathrm{m}$ constituent was detected in the sample but was not quantified. 
Table 6. Concentrations of pesticides detected in ground-water samples from the Chemung River basin, New York, 2003.

[All values are in micrograms per liter and all are from filtered samples. Dashes (--) indicate sample was not analyzed for this constituent.

Well locations are shown in fig. 1.]

\begin{tabular}{|c|c|c|c|c|c|c|c|}
\hline Well no. ${ }^{1}$ & $\begin{array}{c}\text { 2-Chloro- } \\
\text { 4-isopropylamino- } \\
\text { 6-amino-s-triazine } \\
\text { (deethylatrazine) } \\
004040\end{array}$ & $\begin{array}{c}\text { 2-Chloro- } \\
\text { 6-ethylamino- } \\
\text { 4-amino-s-triazine } \\
04038\end{array}$ & $\begin{array}{c}\text { 2-Hydroxy- } \\
\text { 4-isopropylamino- } \\
\text { 6-ethylamino- } \\
s \text {-triazine } \\
50355\end{array}$ & $\begin{array}{c}\text { Atrazine } \\
39632\end{array}$ & $\begin{array}{c}\text { Chlorodiamino- } \\
\text { s-triazine } \\
04039\end{array}$ & $\begin{array}{c}\text { Imazethapyr } \\
50407\end{array}$ & $\begin{array}{c}\text { Metalaxyl } \\
50359\end{array}$ \\
\hline CM 625 & $<.006$ & -- & -- & $<.007$ & -- & -- & -- \\
\hline CM 626 & $<.006$ & $<.04$ & $<.008$ & $<.007$ & & $<.02$ & $<.02$ \\
\hline CM 627 & $<.006$ & -- & -- & $<.007$ & -- & -- & -- \\
\hline CM 632 & $<.006$ & -- & -- & $<.007$ & -- & -- & -- \\
\hline CM 633 & $<.006$ & -- & -- & $<.007$ & -- & -- & -- \\
\hline CM 634 & $<.006$ & -- & -- & $<.007$ & -- & -- & -- \\
\hline CM 635 & ${ }^{\mathrm{E}} .013$ & -- & -- & 0.034 & -- & -- & -- \\
\hline CM 636 & $<.006$ & -- & -- & 0.02 & -- & -- & -- \\
\hline CM 637 & $<.006$ & -- & -- & $<.007$ & -- & -- & -- \\
\hline SB 229 & $<.006$ & $<.04$ & $<.008$ & $<.007$ & $<.01$ & $\mathrm{~m}$ & $<.02$ \\
\hline SB 380 & ${ }^{\mathrm{E}} .006$ & -- & -- & 0.017 & -- & -- & -- \\
\hline SB 382 & ${ }^{\mathrm{E}} .009$ & $\mathrm{~m}$ & $<.008$ & 0.007 & $<.01$ & $<.02$ & $<.02$ \\
\hline SB 390 & $<.006$ & -- & -- & $<.007$ & -- & -- & -- \\
\hline SB 391 & ${ }^{\mathrm{E}} .009$ & -- & -- & 0.01 & -- & -- & -- \\
\hline SB 392 & $<.006$ & -- & -- & $<.007$ & -- & -- & -- \\
\hline SB1408 & & -- & -- & -- & -- & -- & -- \\
\hline SB1408 & ${ }^{\mathrm{E}} .021$ & -- & -- & 0.049 & -- & -- & -- \\
\hline SB1420 & $<.006$ & -- & -- & $<.007$ & -- & -- & -- \\
\hline SB1451 & ${ }^{\mathrm{E}} .008$ & -- & -- & 0.009 & -- & -- & -- \\
\hline SB1470 & $<.006$ & -- & -- & $<.007$ & -- & -- & -- \\
\hline SY1016 & $<.006$ & $<.04$ & $<.008$ & $<.007$ & $<.01$ & $<.02$ & $<.02$ \\
\hline
\end{tabular}

1 SB, Steuben County; CM, Chemung County; SY, Schuyler County. Number is local well-identification number assigned by U.S. Geological Survey.

$\mathrm{E}$ estimated value; constituent was detected in the sample below the laboratory reporting level.

$\mathrm{m}$ constituent was detected in the sample but was not quantified. 
Table 6. Concentrations of pesticides detected in ground-water samples from the Chemung River basin, New York, 2003 (continued).

\begin{tabular}{|c|c|c|c|c|c|c|c|c|}
\hline Well no. ${ }^{1}$ & $\begin{array}{c}\text { Metolachlor } \\
39415 \\
\end{array}$ & $\begin{array}{c}\text { Metribuzin } \\
82630 \\
\end{array}$ & $\begin{array}{c}\text { Prometon } \\
04037 \\
\end{array}$ & $\begin{array}{c}\text { Acetochlor ESA } \\
61029 \\
\end{array}$ & $\begin{array}{c}\text { Alachlor ESA } \\
50009 \\
\end{array}$ & $\begin{array}{c}\text { Alachlor OA } \\
61031 \\
\end{array}$ & $\begin{array}{c}\text { Metolachlor ESA } \\
61043 \\
\end{array}$ & $\begin{array}{c}\text { Metolachlor OA } \\
61044 \\
\end{array}$ \\
\hline CM 82 & $<.013$ & $<.006$ & $<.01$ & $<0.05$ & $<0.05$ & $<0.05$ & $<0.05$ & $<0.05$ \\
\hline CM 625 & $<.013$ & $<.006$ & $<.01$ & $<0.05$ & 0.75 & $<0.05$ & 0.14 & $<0.05$ \\
\hline CM 626 & $<.013$ & $<.006$ & $<.01$ & $<0.05$ & $<0.05$ & $<0.05$ & $<0.05$ & $<0.05$ \\
\hline CM 627 & $<.013$ & $<.006$ & $<.01$ & $<0.05$ & $<0.05$ & $<0.05$ & $<0.05$ & $<0.05$ \\
\hline CM 628 & $<.013$ & $<.006$ & $<.01$ & $<0.05$ & $<0.05$ & $<0.05$ & $<0.05$ & $<0.05$ \\
\hline CM 630 & $<.013$ & $<.006$ & $<.01$ & $<0.05$ & 0.22 & $<0.05$ & 1.49 & $<0.05$ \\
\hline CM 632 & $<.013$ & $<.006$ & $<.01$ & $<0.05$ & $<0.05$ & $<0.05$ & $<0.05$ & $<0.05$ \\
\hline CM 633 & $<.013$ & $<.006$ & $<.01$ & $<0.05$ & $<0.05$ & $<0.05$ & $<0.05$ & $<0.05$ \\
\hline CM 634 & $<.013$ & $<.006$ & $<.01$ & $<0.05$ & $<0.05$ & $<0.05$ & $<0.05$ & $<0.05$ \\
\hline CM 635 & ${ }^{\mathrm{E}} .009$ & $<.006$ & $<.01$ & $<0.05$ & $<0.05$ & $<0.05$ & 0.17 & 0.17 \\
\hline CM 636 & $<.013$ & $<.006$ & $<.01$ & $<0.05$ & $<0.05$ & $<0.05$ & 0.13 & 0.05 \\
\hline CM 637 & $<.013$ & $<.006$ & $<.01$ & $<0.05$ & $<0.05$ & $<0.05$ & 0.05 & $<0.05$ \\
\hline SB 63 & $<.013$ & $<.006$ & $<.01$ & $<0.05$ & $<0.05$ & $<0.05$ & $<0.05$ & $<0.05$ \\
\hline SB 85 & $<.013$ & $<.006$ & $<.01$ & $<0.05$ & $<0.05$ & $<0.05$ & $<0.05$ & $<0.05$ \\
\hline SB 151 & $<.013$ & $<.006$ & $<.01$ & $<0.05$ & 0.5 & $<0.05$ & $<0.05$ & $<0.05$ \\
\hline SB 224 & ${ }^{\mathrm{E}} .011$ & 0.054 & 0.05 & 0.06 & 0.09 & 0.11 & 0.53 & 1.5 \\
\hline SB 229 & $<.013$ & $<.006$ & $<.01$ & $<0.05$ & $<0.05$ & $<0.05$ & $<0.05$ & $<0.05$ \\
\hline SB 380 & $<.013$ & $<.006$ & $<.01$ & $<0.05$ & $<0.05$ & $<0.05$ & 0.15 & 0.05 \\
\hline SB 382 & $<.013$ & $<.006$ & $<.01$ & $<0.05$ & $<0.05$ & $<0.05$ & $<0.05$ & $<0.05$ \\
\hline SB 390 & $<.013$ & $<.006$ & $<.01$ & $<0.05$ & $<0.05$ & $<0.05$ & 0.08 & $<0.05$ \\
\hline SB 391 & $<.013$ & $<.006$ & $<.01$ & $<0.05$ & $<0.05$ & $<0.05$ & 0.23 & $<0.05$ \\
\hline SB 392 & $<.013$ & $<.006$ & $<.01$ & $<0.05$ & $<0.05$ & $<0.05$ & 0.41 & 0.12 \\
\hline SB1408 & -- & -- & -- & $<0.05$ & $<0.05$ & $<0.05$ & 0.08 & $<0.05$ \\
\hline SB1408 & 0.019 & $<.006$ & $<.01$ & $<0.05$ & $<0.05$ & $<0.05$ & 0.16 & 0.11 \\
\hline SB1420 & $<.013$ & $<.006$ & $<.01$ & $<0.05$ & $<0.05$ & $<0.05$ & $<0.05$ & $<0.05$ \\
\hline SB1451 & $<.013$ & $<.006$ & $<.01$ & $<0.05$ & $<0.05$ & $<0.05$ & 0.23 & $<0.05$ \\
\hline SB1470 & $<.013$ & $<.006$ & $<.01$ & $<0.05$ & $<0.05$ & $<0.05$ & $<0.05$ & $<0.05$ \\
\hline SY1016 & $<.013$ & $<.006$ & $<.01$ & $<0.05$ & $<0.05$ & $<0.05$ & $<0.05$ & $<0.05$ \\
\hline
\end{tabular}

1 SB, Steuben County; CM, Chemung County; SY, Schuyler County. Number is local well-identification number assigned by U.S. Geological Survey.

$\mathrm{E}$ estimated value; constituent was detected in the sample below the laboratory reporting level.

ESA - Ethanesulfonic acid metabolite.

OA - Oxanilic acid metabolite. 
Table 7. Concentrations of volatile organic compounds (VOCs) in ground-water samples from the Chemung River basin, New York, 2003.

[All values are in micrograms per liter and all are from unfiltered samples. Locations are shown in fig. 1.]

\begin{tabular}{|c|c|c|c|c|c|c|c|c|c|c|c|}
\hline Well no. ${ }^{1}$ & $\begin{array}{c}1,1,1- \\
\text { Trichloro- } \\
\text { ethane } \\
34506\end{array}$ & $\begin{array}{c}\text { 1,1-Dichloro- } \\
\text { ethane } \\
34496\end{array}$ & $\begin{array}{c}\text { Bromo- } \\
\text { dichloro- } \\
\text { methane } \\
32101\end{array}$ & $\begin{array}{c}\text { cis-1,2- } \\
\text { Dichloro- } \\
\text { ethene } \\
77093\end{array}$ & $\begin{array}{c}\text { Dibromo- } \\
\text { chloro- } \\
\text { methane } \\
32105\end{array}$ & $\begin{array}{l}\text { Methyl tert- } \\
\text { butyl ether } \\
78032\end{array}$ & $\begin{array}{c}\text { Tetrachloro- } \\
\text { ethene } \\
34475 \\
\end{array}$ & $\begin{array}{c}\text { Toluene } \\
34010 \\
\end{array}$ & $\begin{array}{l}\text { Tribromo- } \\
\text { methane } \\
32104\end{array}$ & $\begin{array}{c}\text { Trichloro- } \\
\text { ethene } \\
39180 \\
\end{array}$ & $\begin{array}{c}\text { Trichloro- } \\
\text { methane } \\
32106\end{array}$ \\
\hline CM 82 & 2.1 & $<0.1$ & $<0.1$ & $<0.1$ & $<0.2$ & $<0.2$ & $<0.1$ & $<0.1$ & $<0.2$ & $<0.1$ & $<0.1$ \\
\hline CM 625 & $<.1$ & $<.1$ & $<.1$ & $<.1$ & $<.2$ & $<.2$ & $<.1$ & $<.1$ & $<.2$ & $<.1$ & $<.1$ \\
\hline CM 626 & $<.1$ & $<.1$ & $<.1$ & $<.1$ & $<.2$ & $<.2$ & $<.1$ & $<.1$ & $<.2$ & $<.1$ & $<.1$ \\
\hline CM 627 & $<.1$ & $<.1$ & $<.1$ & $<.1$ & $<.2$ & ${ }^{\mathrm{E}} .2$ & $<.1$ & $<.1$ & $<.2$ & $<.1$ & $<.1$ \\
\hline CM 628 & $<.1$ & $<.1$ & $<.1$ & $<.1$ & $<.2$ & $<.2$ & $<.1$ & $<.1$ & $<.2$ & $<.1$ & $<.1$ \\
\hline СМ 629 & $<.1$ & $<.1$ & $<.1$ & $<.1$ & $<.2$ & $<.2$ & $<.1$ & $<.1$ & $<.2$ & $<.1$ & $<.1$ \\
\hline CM 630 & $<.1$ & $<.1$ & $<.1$ & $<.1$ & $<.2$ & $<.2$ & $<.1$ & $<.1$ & $<.2$ & 0.1 & $<.1$ \\
\hline CM 631 & $<.1$ & $<.1$ & $<.1$ & $<.1$ & $<.2$ & $<.2$ & $<.1$ & $<.1$ & $<.2$ & $<.1$ & $<.1$ \\
\hline CM 632 & $<.1$ & $<.1$ & $<.1$ & $<.1$ & $<.2$ & $<.2$ & $<.1$ & $<.1$ & $<.2$ & $<.1$ & $<.1$ \\
\hline CM 633 & $<.1$ & $<.1$ & $<.1$ & $<.1$ & $<.2$ & $<.2$ & $<.1$ & $<.1$ & $<.2$ & $<.1$ & $<.1$ \\
\hline CM 634 & $<.1$ & $<.1$ & $<.1$ & $<.1$ & $<.2$ & $<.2$ & $<.1$ & $<.1$ & $<.2$ & $<.1$ & $<.1$ \\
\hline CM 635 & $<.1$ & $<.1$ & $<.1$ & $<.1$ & $<.2$ & $<.2$ & 0.4 & $<.1$ & $<.2$ & $<.1$ & 0.2 \\
\hline CM 636 & $<.1$ & $<.1$ & $<.1$ & 0.2 & $<.2$ & $<.2$ & 1.7 & $<.1$ & $<.2$ & 0.2 & 0.3 \\
\hline CM 637 & $<.1$ & $<.1$ & $<.1$ & $<.1$ & $<.2$ & $<.2$ & $<.1$ & $<.1$ & $<.2$ & $<.1$ & 0.1 \\
\hline CM 904 & $<.1$ & $<.1$ & $<.1$ & $<.1$ & $<.2$ & $<.2$ & $<.1$ & 0.3 & $<.2$ & $<.1$ & $<.1$ \\
\hline CM 954 & $<.1$ & $<.1$ & $<.1$ & $<.1$ & $<.2$ & $<.2$ & $<.1$ & $<.1$ & $<.2$ & $<.1$ & $<.1$ \\
\hline SB 63 & 0.4 & $<.1$ & $<.1$ & $<.1$ & $<.2$ & $<.2$ & 1.4 & $<.1$ & $<.2$ & 0.7 & $<.1$ \\
\hline SB 85 & 0.3 & 0.2 & $<.1$ & $<.1$ & $<.2$ & 0.4 & $<.1$ & $<.1$ & $<.2$ & $<.1$ & $<.1$ \\
\hline SB 151 & $<.1$ & $<.1$ & 0.2 & $<.1$ & 0.2 & $<.2$ & $<.1$ & $<.1$ & $<.2$ & $<.1$ & 0.8 \\
\hline SB 224 & 0.1 & $<.1$ & 0.2 & $<.1$ & 0.3 & $<.2$ & $<.1$ & $<.1$ & 0.3 & $<.1$ & $<.1$ \\
\hline SB 229 & $<.1$ & $<.1$ & $<.1$ & $<.1$ & $<.2$ & $<.2$ & $<.1$ & $<.1$ & $<.2$ & $<.1$ & $<.1$ \\
\hline SB 380 & $<.1$ & $<.1$ & $<.1$ & $<.1$ & $<.2$ & $<.2$ & $<.1$ & $<.1$ & $<.2$ & $<.1$ & $<.1$ \\
\hline SB 382 & $<.1$ & $<.1$ & $<.1$ & $<.1$ & $<.2$ & $<.2$ & $<.1$ & $<.1$ & $<.2$ & $<.1$ & $<.1$ \\
\hline SB 390 & $<.1$ & $<.1$ & $<.1$ & $<.1$ & $<.2$ & $<.2$ & $<.1$ & $<.1$ & $<.2$ & $<.1$ & $<.1$ \\
\hline SB 391 & $<.1$ & $<.1$ & 0.3 & $<.1$ & 0.2 & $<.2$ & $<.1$ & $<.1$ & $<.2$ & $<.1$ & 0.6 \\
\hline SB 392 & $<.1$ & $<.1$ & $<.1$ & $<.1$ & $<.2$ & $<.2$ & $<.1$ & $<.1$ & $<.2$ & $<.1$ & $<.1$ \\
\hline SB1066 & $<.1$ & $<.1$ & $<.1$ & $<.1$ & $<.2$ & $<.2$ & $<.1$ & $<.1$ & $<.2$ & $<.1$ & $<.1$ \\
\hline SB1066 & $<.1$ & $<.1$ & $<.1$ & $<.1$ & $<.2$ & $<.2$ & $<.1$ & $<.1$ & $<.2$ & $<.1$ & $<.1$ \\
\hline SB1077 & $<.1$ & $<.1$ & $<.1$ & $<.1$ & $<.2$ & $<.2$ & $<.1$ & $<.1$ & $<.2$ & $<.1$ & 0.1 \\
\hline SB1350 & $<.1$ & $<.1$ & $<.1$ & $<.1$ & $<.2$ & $<.2$ & $<.1$ & $<.1$ & $<.2$ & $<.1$ & $<.1$ \\
\hline SB1408 & $<.1$ & $<.1$ & $<.1$ & $<.1$ & $<.2$ & $<.2$ & $<.1$ & $<.1$ & $<.2$ & $<.1$ & 0.1 \\
\hline SB1408 & $<.1$ & $<.1$ & 0.2 & $<.1$ & $<.2$ & $<.2$ & $<.1$ & $<.1$ & $<.2$ & $<.1$ & 1.9 \\
\hline SB1420 & $<.1$ & $<.1$ & $<.1$ & $<.1$ & $<.2$ & $<.2$ & $<.1$ & $<.1$ & $<.2$ & $<.1$ & $<.1$ \\
\hline SB1447 & $<.1$ & $<.1$ & $<.1$ & $<.1$ & $<.2$ & $<.2$ & $<.1$ & $<.1$ & $<.2$ & $<.1$ & $<.1$ \\
\hline SB1451 & $<.1$ & $<.1$ & $<.1$ & $<.1$ & $<.2$ & $<.2$ & 0.1 & $<.1$ & $<.2$ & $<.1$ & $<.1$ \\
\hline SB1457 & $<.1$ & $<.1$ & $<.1$ & $<.1$ & $<.2$ & $<.2$ & $<.1$ & $<.1$ & $<.2$ & $<.1$ & $<.1$ \\
\hline SB1470 & $<.1$ & $<.1$ & $<.1$ & $<.1$ & $<.2$ & $<.2$ & $<.1$ & $<.1$ & $<.2$ & $<.1$ & $<.1$ \\
\hline SY 911 & $<.1$ & $<.1$ & $<.1$ & $<.1$ & $<.2$ & $<.2$ & $<.1$ & $<.1$ & $<.2$ & $<.1$ & $<.1$ \\
\hline SY1016 & $<.1$ & $<.1$ & $<.1$ & $<.1$ & $<.2$ & $<.2$ & $<.1$ & $<.1$ & $<.2$ & $<.1$ & $<.1$ \\
\hline
\end{tabular}

\footnotetext{
${ }^{1}$ SB, Steuben County; CM, Chemung County; SY, Schuyler County. Number is local well-identification number assigned by U.S. Geological Survey.

$\mathrm{E}$ estimated value.
} 
Table 8. Concentrations of bacteria in ground-water samples from the Chemung River basin, New York, 2003.

\begin{tabular}{|c|c|c|c|c|}
\hline Well no. ${ }^{1}$ & $\begin{array}{c}\text { Esherichia coli }^{2} \\
\text { (per } 100 \mathrm{~mL})\end{array}$ & $\begin{array}{c}\text { Fecal coliform } \\
\text { (colonies per } \\
100 \mathrm{~mL} \text { ) }\end{array}$ & $\begin{array}{l}\text { Standard plate } \\
\text { count (per } \mathrm{mL} \text { ) }\end{array}$ & $\begin{array}{c}\text { Total coliform }{ }^{2} \\
\text { colonies per } \\
100 \mathrm{~mL} \text { ) }\end{array}$ \\
\hline CM 82 & -- & $<5$ & $<1$ & neg \\
\hline CM 625 & -- & $<5$ & 7 & neg \\
\hline СM 626 & -- & $<5$ & 6 & neg \\
\hline CM 627 & -- & $<5$ & $<1$ & neg \\
\hline CM 628 & pos & $<5$ & 9 & pos \\
\hline CM 629 & & 600 & $<1$ & neg \\
\hline CM 630 & neg & $<5$ & 3 & pos \\
\hline CM 631 & -- & $<5$ & $<1$ & neg \\
\hline CM 632 & -- & $<5$ & $<1$ & neg \\
\hline CM 633 & -- & $<5$ & 86 & neg \\
\hline CM 634 & -- & $<5$ & 2 & neg \\
\hline CM 635 & -- & $<5$ & 1 & neg \\
\hline CM 636 & neg & $<5$ & 3 & pos \\
\hline CM 637 & neg & $<5$ & 1 & pos \\
\hline CM 904 & -- & $<5$ & 24 & neg \\
\hline CM 954 & -- & $<5$ & 130 & neg \\
\hline SB 63 & -- & $<5$ & $<1$ & neg \\
\hline SB 85 & -- & $<5$ & $<1$ & neg \\
\hline SB 151 & neg & $<5$ & 2 & pos \\
\hline SB 224 & -- & $<5$ & $<1$ & neg \\
\hline SB 229 & -- & 15 & 10 & neg \\
\hline SB 380 & -- & $<5$ & 2 & neg \\
\hline SB 382 & -- & $<5$ & 1 & neg \\
\hline SB 390 & -- & 5 & 5 & neg \\
\hline SB 391 & -- & $<5$ & 2 & neg \\
\hline SB 392 & -- & $<5$ & 1 & neg \\
\hline SB1066 & pos & & $<1$ & pos \\
\hline SB1066 & pos & 20 & 27 & pos \\
\hline SB1077 & -- & $<5$ & 3 & neg \\
\hline SB1350 & -- & $<5$ & 1400 & neg \\
\hline SB1408 & pos & 530 & 680 & pos \\
\hline SB1408 & pos & 20 & 120 & pos \\
\hline SB1420 & --- & $<5$ & 93 & neg \\
\hline SB1447 & neg & $<5$ & 140 & pos \\
\hline SB1451 & -- & $<5$ & 12 & neg \\
\hline SB1457 & -- & $<5$ & 17 & neg \\
\hline SB1470 & pos & 10 & 87 & pos \\
\hline SY 911 & neg & $<5$ & 1900 & pos \\
\hline SY1016 & -- & $<5$ & 76 & neg \\
\hline
\end{tabular}

${ }^{1}$ SB, Steuben County; CM, Chemung County; SY, Schuyler County. Number is local well-identification number assigned by U.S. Geological Survey.

2 neg, negative result (organism not detected); pos, positive result (organism detected).

-- indicates organism was not analyzed for in sample. 